\title{
Renewable (Bis)pyrrolidone Based Monomers as Components for Thermally Curable and Enzymatically Depolymerizable 2-Oxazoline Thermoset Resins
}

\author{
Manta Roy, Geert J. Noordzij, Yara van den Boomen, Sanjay Rastogi, ${ }^{\circledR}$ and Carolus H. R. M. Wilsens*(i)
}

Aachen-Maastricht Institute for Biobased Material (AMIBM), Maastricht University, Urmonderbaan 22, 6167 RD Geleen, The

Netherlands

\section{Supporting Information}

ABSTRACT: In this study we describe the synthesis of bis(pyrrolidone) based dicarboxylic acids from itaconic acid and their application in 2-oxazoline resins for fully renewable thermoset materials. The monomers are obtained using a bulk aza-Michael addition of a diamine and two itaconic acid molecules using a catalytic amount of water. The monomers can be isolated in high purity after recrystallization, though their yield proved to be highly dependent on the selected diamine spacer length: In general, only the dicarboxylic acids containing diamines with an even number of methylene spacers are isolated in high yields. Through NMR, GPC, and FTIR analysis we demonstrate that these bis(pyrrolidone) based dicarboxylic acids exhibit significantly enhanced curing rates in 2-oxazoline resins compared to resins containing aliphatic dicarboxylic acids such as sebacic acid. Overall, we demonstrate that the rate of 2-oxazoline ring-opening addition with carboxylic acid functionalities is determined by the used dicarboxylic acid, whereas the ring-opening addition of the 2-oxazoline functionality with amide groups is determined by the used bis(2-oxazoline) compound. The thermosets obtained after curing proved to be readily plasticized by water, opening up possibilities for enzymatic degradation.

KEYWORDS: Bis(2-oxazoline), Itaconic acid, Pyrrolidone, Thermoset

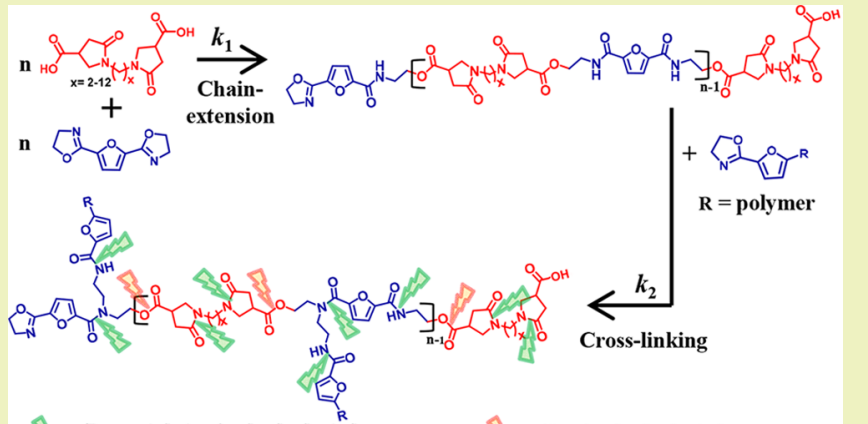

$\mathbb{R}=$ Potential site for hydrolysis by protease $\$$ Site for hydrolysis by water

\section{INTRODUCTION}

With the continuous growth of the plastic industry, an increasing amount of resources will be required for the production of polymeric materials in the future. To this end, both academia and industry have a strong focus to develop renewable, recyclable, and/or degradable polymer materials that can ensure the sustainability of the polymer industry. Particular monomers that contribute to this endeavor are the renewable 2,5furandicarboxylic acid, ${ }^{1}$ and itaconic acid. ${ }^{2,3}$ 2,5-Furandicarboxylic acid, generally obtained from hydroxymethyl furfural or its derivatives, ${ }^{4}$ has proven to exhibit excellent gas permeability properties in thermoplastic materials ${ }^{5}$ and has also proven applicable for thermosetting resins. ${ }^{6}$ Itaconic acid, having two carboxylic functionalities combined with the presence of a vinyl group, has proven to be of interest for the synthesis of renewable polyesters, ${ }^{7-11}$ polyester resins, ${ }^{12,13}$ polyamides, ${ }^{14-17}$ and other polymers. $^{12,18-20}$ One particularly interesting application of itaconic acid is its ability to undergo the aza-Michael addition reaction with amines, followed by ring closure and the generation of a carboxylic acid functionalized pyrrolidone ring. ${ }^{17,21}$ The resulting pyrrolidone based carboxylic acids are readily polymerized using conventional polycondensation methods, generally yielding amorphous and degradable polymer materi- 
Scheme 1. Expected Reactions Occurring During Thermally Initiated Ring-Opening Addition of FDCAox with the Bis(pyrrolidone) Dicarboxylic Acid Monomers Explored in This Study

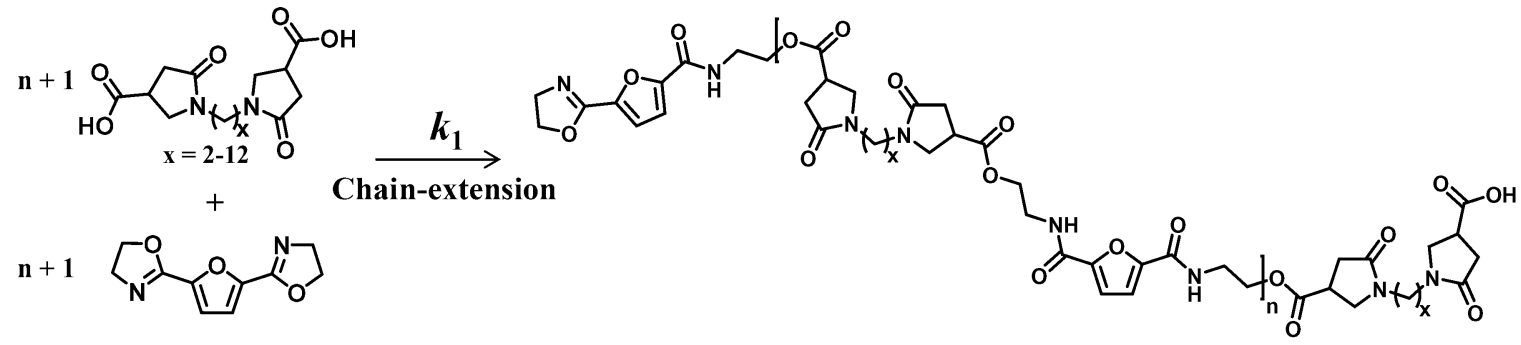

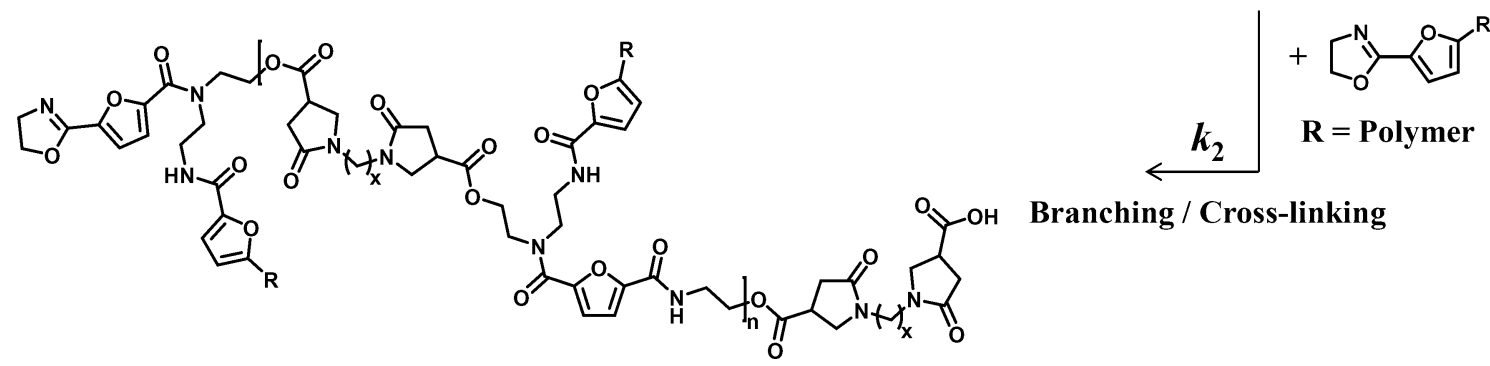

Resins containing bis(2-oxazoline)s and dicarboxylic acids are known to undergo a thermal ring-opening addition polymerization reaction, generating poly(ester-amide)s, which has been earlier communicated by groups of Bohme, ${ }^{47-49}$ Sano, ${ }^{50,51}$ Nery $^{52}$ and others ${ }^{37,39,53-56}\left(k_{1}\right.$ in Scheme 1$)$. In turn, the generated amide groups are participating in a ring-opening addition reaction with 2-oxazoline moieties, thereby forming tertiary amide bonds $\left(k_{2}\right.$ in Scheme 1$)$. In fact, this mechanism is responsible for the cross-linking of the 2-oxazoline resins, where the cross-link density is controlled by the excess of bis(2oxazoline) monomer. ${ }^{50,51,57}$ In previous work we have demonstrated that the application of renewable monomers in 2-oxazoline resins can be beneficial for the curing process: Besides being renewable in nature, the application of a 2,5-FDCA based bis(2-oxazoline) (FDCAox) was shown to be selectively enhancing this cross-linking reaction, thereby significantly suppressing the required curing time.

In the present study we evaluate the performance of itaconic acid based bis(pyrrolidone) dicarboxylic acid monomers in 2oxazoline resins (Scheme 1). The effect of the dicarboxylic acids on the curing process is explored using NMR spectroscopy, FTIR spectroscopy, and GPC chromatography. Additionally, the thermal behavior of the developed thermosets is investigated while particular attention is paid to the plasticizing effect of water in these materials. Lastly, preliminary enzymatic degradation studies are performed to evaluate whether these thermosets can be depolymerized in nature.

\section{EXPERIMENTAL SECTION}

Materials. Itaconic acid, 1,2-diaminoethane, 1,3-diaminopropane, 1,4-diaminobutane, 1,5-diaminopentane, 1,6-diaminohexane, 1,7-diaminoheptane, 1,8-diaminooctane, 1,9-diaminononane, 1,10-diaminodecane, and 1,12-diaminododecane were purchased from Sigma-Aldrich. Sebacic acid (SeA), 2-chloroethylamine hydrochloride, triphenylphosphite (TPP), thionyl chloride, sodium hydroxide, and potassium hydroxide were purchased from Sigma. 1,3-Bis(4,5-dihydrooxazol-2yl)benzene (IAox) was purchased from TCI Europe. 2,5-Furandicarboxylic acid (2,5-FDCA) was obtained from Atomole, China (>99.5 wt $\%$, GC-MS). 2,5-Bis(4,5-dihydrooxazol-2-yl)furan (FDCAox) was synthesized according to the previously reported procedure. ${ }^{57}$ The chemicals are used as received, unless it is otherwise described.
General Synthesis Procedure of the Bis(pyrrolidone) Dicarboxylic Acids. The bis(pyrrolidone) based dicarboxylic acids were synthesized using a bulk reaction between itaconic acid and an $\alpha, \omega$ aliphatic diamine in a 2:1 molar ratio. The obtained monomers are abbreviated as $\mathrm{BP}^{-\mathrm{C}_{x}}$ where $x$ denotes the methylene spacer length of the used diamine. As a representative example, the synthesis of $N, N^{\prime}$ octamethylene-bis(pyrrolidone-4-carboxylic acid), hence, $\mathrm{BP}^{-\mathrm{C}_{8}}$, is described: Itaconic acid $(9.02 \mathrm{~g}, 0.069 \mathrm{mmol})$ and 1,8-diaminooctane $(5 \mathrm{~g}, 0.035 \mathrm{mmol})$ were added to a $100 \mathrm{~mL}$ round-bottom flask. The mixture was heated to $130{ }^{\circ} \mathrm{C}$ and was allowed to stir for $18 \mathrm{~h}$ in the presence of a catalytic amount of distilled water to yield a yellow viscous liquid. The product was obtained as white crystals after recrystallization from a mixture of methanol and ethyl acetate, followed by filtration and washing with ethyl acetate, and drying in vacuo overnight at $50^{\circ} \mathrm{C}$. The yield of the synthesized monomer is shown in Table 1 . The yield is

Table 1. Yield, Thermal Stability, and Thermal Behavior of the BP-C ${ }_{x}$ Monomers

\begin{tabular}{|c|c|c|c|c|}
\hline entry & yield $^{a}(\%)$ & $T_{\mathrm{m}}{ }^{b}\left({ }^{\circ} \mathrm{C}\right)$ & $T_{\mathrm{g}}^{b}\left({ }^{\circ} \mathrm{C}\right)$ & $T_{\mathrm{d}}^{c}\left({ }^{\circ} \mathrm{C}\right)$ \\
\hline BP-C ${ }_{2}$ & 95 & 238 & 48.5 & 272 \\
\hline BP-C ${ }_{3}$ & 90 & 194 & 31.3 & 269 \\
\hline BP-C 4 & 85 & 196 & 24.1 & 274 \\
\hline BP-C ${ }_{5}$ & 65 & 156 & 22.3 & 275 \\
\hline BP-C 6 & 75 & 181 & 18.7 & 272 \\
\hline $\mathrm{BP}^{-C_{8}}$ & 85 & 153 & 12.6 & 274 \\
\hline BP-C ${ }_{9}$ & 30 & 81 & 4.9 & 271 \\
\hline $\mathrm{BP}-\mathrm{C}_{10}$ & 90 & 131 & 3.1 & 274 \\
\hline BP-C $C_{12}$ & 90 & 145 & 3.7 & 271 \\
\hline
\end{tabular}

${ }^{a}$ Yield determined after purification by recrystallization. ${ }^{b}$ Determined from the DSC analysis, whereas the peak melting temperature $\left(T_{\mathrm{m}}\right)$ is determined from the first heating run and the glass transition temperature $\left(T_{\mathrm{g}}\right)$ is determined from the second heating run. ${ }^{c}$ Thermal degradation temperature determined from TGA analysis, where the $T_{\mathrm{d}}$ denotes the onset point for degradation.

measured gravimetrically, while the purity is traced with ${ }^{1} \mathrm{H}$ NMR. ${ }^{1} \mathrm{H}$ NMR analysis $\left(\mathrm{CDCl}_{3}+d\right.$-TFA, $\left.300 \mathrm{MHz}\right): \delta 3.80(\mathrm{~m}, 4 \mathrm{H}), 3.44(\mathrm{~m}$, $4 \mathrm{H}), 3.31(\mathrm{~m}, 2 \mathrm{H}), 2.99(\mathrm{~d}, 2 \mathrm{H}, J=7.9 \mathrm{~Hz}), 1.57(\mathrm{~m}, 4 \mathrm{H}), 1.30(\mathrm{~m}, 8 \mathrm{H})$. ${ }^{13} \mathrm{C}$ NMR $\left(\mathrm{CDCl}_{3}+d\right.$-TFA, $\left.300 \mathrm{MHz}\right): \delta 178.2(\mathrm{C}=\mathrm{OOH}), 175.0$ $(\mathrm{NC}=\mathrm{O}), 49.7\left(\mathrm{NCH}_{2}\right.$ ring $), 43.4\left(\mathrm{NCH}_{2}\right.$ spacer $), 35.7$ ( $\mathrm{CH}$ ring $), 33.8$ $\left(\mathrm{CH}_{2}\right.$ ring $), 28.6\left(\mathrm{CH}_{2}\right.$ spacer $), 26.5\left(\mathrm{CH}_{2}\right.$ spacer $), 26.1\left(\mathrm{CH}_{2}\right.$ spacer $)$. 
Scheme 2. Aza-Michael Addition of Various Diamines with Itaconic Acid, Followed by Intramolecular Cyclization ${ }^{a}$

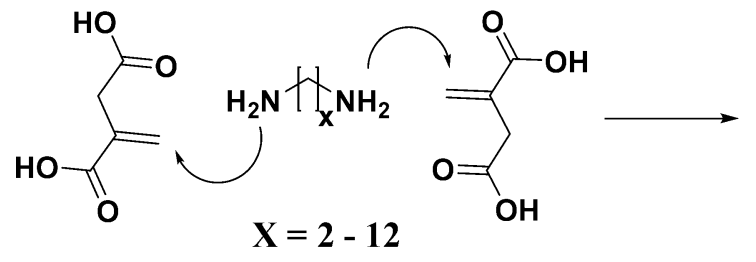<smiles>[Y][C@@]1(C)CC(=O)N(CC(CC(=O)O)C(=O)O)C1</smiles>

${ }^{a_{T}}$ The ensuing monomers are abbreviated as BP-C $\mathrm{C}_{x}$, where $x$ stands for the number of methylene groups in the used diamine spacer. For example, the $N, N^{\prime}$-octamethylene-bis(pyrrolidone-4-carboxylic acid) monomer based on 1,8-diaminooctane is named BP- $\mathrm{C}_{8}$.
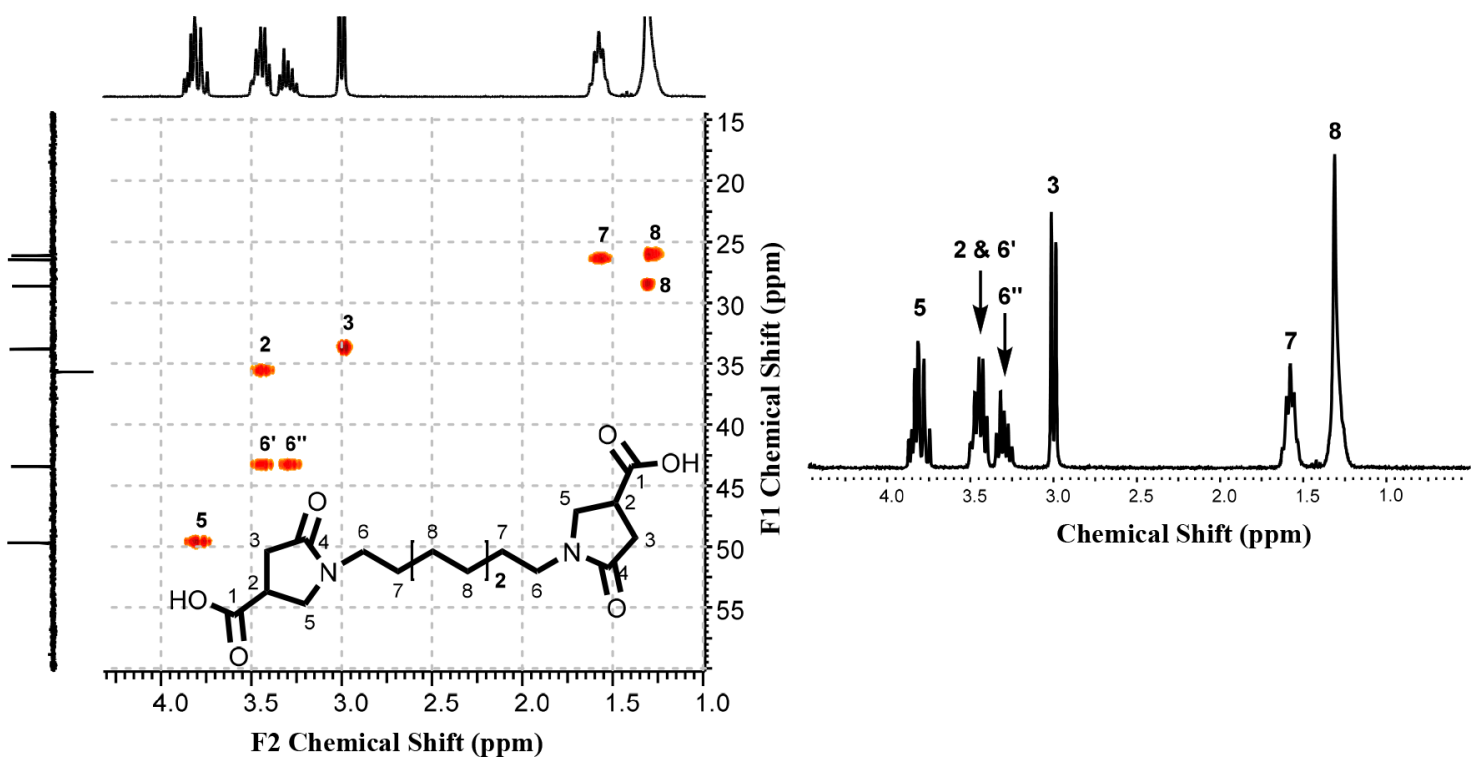

Figure 1. HSQC $\left({ }^{1} \mathrm{H}-{ }^{13} \mathrm{C}\right.$ DEPT) spectrum (left) and ${ }^{1} \mathrm{H}$ NMR spectrum (right) and the corresponding peak assignment of the BP-C $\mathrm{C}_{8}$ monomer, taken in $\mathrm{CDCl}_{3} / d$-TFA as solvent.

For the detailed overview of the synthesis and NMR analysis of the BP$\mathrm{C}_{x}$ monomers, we refer to the Supporting Information.

General Melt Polymerization Procedure. Reaction mixtures containing the desired molar ratio of $\mathrm{BP}^{-\mathrm{C}_{x}}$ and bis(2-oxazoline) were mixed using a mortar and pestle. When desired, 1 wt \% of triphenyl phosphite (TPP) was added as catalyst. The obtained reaction mixtures were polymerized on small scale $(10 \mathrm{mg}$ in a HPLC vial) or were polymerized on a $3 \mathrm{~g}$ scale after loading into a $250 \mathrm{~mL}$ round-bottom flask fitted with a mechanical stirrer. The polymerizations were performed at $180{ }^{\circ} \mathrm{C}$ for $60 \mathrm{~min}$ to ensure full conversion. Regular sampling was performed to monitor the reaction over time.

Characterization Methods. ${ }^{1} \mathrm{H}$ NMR and ${ }^{13} \mathrm{C}$ NMR spectroscopy was performed with a Bruker Ultrashield 300 spectrometer $(300 \mathrm{MHz}$ magnetic field). Samples were prepared by dissolving $10 \mathrm{mg}$ of monomer or polymer in $0.5 \mathrm{~mL}$ of deuterated dimethyl sulfoxide $\left(\mathrm{DMSO}-\mathrm{d}_{6}\right)$, in a mixture of deuterated chloroform $\left(\mathrm{CDCl}_{3}\right)$ and deuterated trifluoroacetic acid (TFA- $d$ ), or in deuterated dimethylformamide (DMF- $\left.d_{7}\right)$. All spectra were referenced against tetramethylsilane (TMS).

Molecular weight of the synthesized poly(ester amide)s was determined via gel permeation chromatography (GPC). The polymers $(5.0 \mathrm{mg}$ ) were dissolved in $1.5 \mathrm{~mL}$ of $1,1,1,3,3,3$-hexafluoroisopropanol (HFIP) containing $0.019 \%$ sodium trifluoroacetate. After full dissolution, the mixtures were filtered over a $0.2 \mu \mathrm{m}$ PTFE syringe filter before injection. The GPC apparatus was calibrated with poly(methyl methacrylate) standards. Two PFG combination medium microcolumns with $7 \mu \mathrm{m}$ particle size $(4.6 \mathrm{~mm} \times 250 \mathrm{~mm}$, separation range $100-1.000 .000 \mathrm{Da}$ ) and precolumn PFG combination medium with $7 \mu \mathrm{m}$ particle size $(4.6 \mathrm{~mm} \times 30 \mathrm{~mm})$ with refractive index detector (RI) were used in order to determine molecular weights and dispersities.

Attenuated total reflection Fourier transform infrared spectroscopy (ATR-FTIR) was performed using a PerkinElmer Spotlight 400 equipped with a PIKE GladiATR, dual mode MCT (mercury cadmium telluride) detector with an array or a temperature-stabilized DTGS (deuterated triglycine sulfate) as a standard configuration. Polymerization and curing reactions were monitored online for $1 \mathrm{~h}$ at the desired reaction temperature between 140 and $220^{\circ} \mathrm{C}$. Spectra were collected every $2 \mathrm{~s}$ in the range $4000-450 \mathrm{~cm}^{-1}$ with a spectral resolution of 4 $\mathrm{cm}^{-1}$.

Thermal stability of the $\mathrm{BP}_{-} \mathrm{C}_{x}$ monomers and poly(ester amide)s synthesized in this study was evaluated using thermogravimetric analysis (TGA). Experiments were performed on a TA Instruments TGA Q500 in a nitrogen rich atmosphere. Samples were heated from 20 to $700{ }^{\circ} \mathrm{C}$, at a heating rate of $10^{\circ} \mathrm{C} / \mathrm{min}$. Differential scanning calorimetry (DSC) was performed to identify the thermal transitions of the developed materials using a TA Instruments DSC Q2000. Two heating and cooling runs were performed at heating and cooling rates of $10^{\circ} \mathrm{C} / \mathrm{min}$. The melting temperature $\left(T_{\mathrm{m}}\right)$ was determined from the first heating run while the glass transition temperatures of the $\mathrm{BP}_{-} \mathrm{C}_{x}$ monomers were determined from the second heating run.

Enzymatic Depolymerization and Solubilization Procedures. The solubility and enzymatic degradation were evaluated on the developed thermosets obtained after curing of an equimolar mixture bis(2-oxazoline) and $\mathrm{BP}^{-\mathrm{C}_{x}}$ monomers for $1 \mathrm{~h}$ at $180^{\circ} \mathrm{C}$. In general, 30 $\mathrm{mg}$ of the thermoset was added to water or tris buffer solution $(1 \mathrm{~mL}$, $100 \mathrm{mM}, \mathrm{pH} 8)$, with or without Bascillus $S p(0.8 \mathrm{~mL}, 16$ units $/ \mathrm{mL}$, Sigma-Aldrich) enzyme. The enzyme was added to the polymer 
together with a $\mathrm{CaCl}_{2}$ solution $(0.01 \mathrm{M})$ at $50{ }^{\circ} \mathrm{C}$ in order to enforce depolymerization and dissolve the poly(ester amide) thermosets. ${ }^{58-60}$

\section{RESULTS AND DISCUSSION}

Bis(pyrrolidone) Based Dicarboxylic Acid (BP-C $C_{x}$ ) Synthesis. Previous reports on bis(pyrrolidone) based dicarboxylic acids from itaconic acid and different aliphatic diamine spacers (Scheme 2) often involve synthesis from water as both reaction medium and catalyst. ${ }^{11,17}$ These dicarboxylic acids, generally obtained as viscous oily liquids, can be used directly for polymerization or are first isolated after several trituration steps. ${ }^{15}$ One potential problem with these methods is that residual unreacted primary or secondary amine groups may be present in the final product. The presence of such amine impurities is detrimental for thermal curing polymerizations with 2-oxazolines as they are known to negatively affect the reactivity of the mixture. ${ }^{61}$ Additionally, the presence of unreacted itaconic acid or amines will affect the stoichiometry and might hamper build-up of molecular weight. For this purpose, we have slightly modified the synthesis and purification methods provided in the literature: ${ }^{11,15}$ First the synthesis is performed in bulk at 130 $180^{\circ} \mathrm{C}$ in the presence of a catalytic amount of water. After reaction overnight, the formed oily yellow liquid is subjected to reduced pressure to remove the water generated during the reaction. Second, the monomers are dissolved and recrystallized from a methanol/ethyl acetate mixture to obtain them in high purity.

NMR spectroscopy analysis was used to confirm the structure and purity of the synthesized $\mathrm{BP}_{-} \mathrm{C}_{x}$ monomers. Figure 1 shows the $\mathrm{HSQC}$ and ${ }^{1} \mathrm{H}$ NMR spectra for the $\mathrm{BP}-\mathrm{C}_{8}$ monomer as a representative example. In general, the signals of the methylene units between the pyrrolidone groups are found at 1.3, 1.7, and 3.3-3.4 ppm (signals 8, 7, and 6, respectively, in Figure 1) where the resonances $6^{\prime}$ and $6^{\prime \prime}$ are split due to their interaction with the neighboring carbonyl of the pyrrolidone ring. Similarly, the presence of the pyrrolidone ring is detected by the resonances found around $3.3 \mathrm{ppm}$ (signal 2), $3.0 \mathrm{ppm}$ (signal 3), and 3.8 ppm (signal 5). Although the carbonyl signals in the pyrrolidone rings (signals 1 and 4 ) are not displayed in Figure 1, they are found at 178 and $175 \mathrm{ppm}$, respectively, in ${ }^{13} \mathrm{C}$ NMR analysis. Overall, from NMR analysis we observe that the inclusion of recrystallization steps in our adapted synthesis and purification method yields the desired compounds with good purity as no traces of impurities were detected. For detailed NMR analysis of the other $\mathrm{BP}^{-\mathrm{C}_{x}}$ monomers, we refer to the Supporting Information.

With respect to the yield of the monomers after purification, we observe that the recrystallization process proceeds rapidly and results in high isolated yields for monomers with short $\left(\mathrm{BP}^{\mathrm{B}} \mathrm{C}_{2}\right.$, $B P-C_{3}$, and $\mathrm{BP}_{-} \mathrm{C}_{4}$ ) or long (BP- $\mathrm{C}_{10}$ and $\mathrm{BP}-\mathrm{C}_{12}$ ) diamine spacers. However, recrystallization proved more challenging for the BP- $\mathrm{C}_{x}$ monomers having 5-9 methylene spacers between the pyrrolidone rings. Especially when using odd diamine spacers, recrystallization from solvent proved challenging, resulting in decreased isolated yields as is visible from Table 1 . In fact, the $\mathrm{BP}_{-} \mathrm{C}_{7}$ monomer proved impossible to crystallize using the described purification procedure, even upon prolonged recrystallization times at $-20^{\circ} \mathrm{C}$.

The obtained $\mathrm{BP}^{-\mathrm{C}_{x}}$ crystallites were tested for their thermal stability and melting behavior using TGA and DSC analysis. Overall, the monomers are stable up to temperatures well above their melting temperatures (Figure 2 and Table 1): In general, an onset of degradation is observed around $270{ }^{\circ} \mathrm{C}$ for all

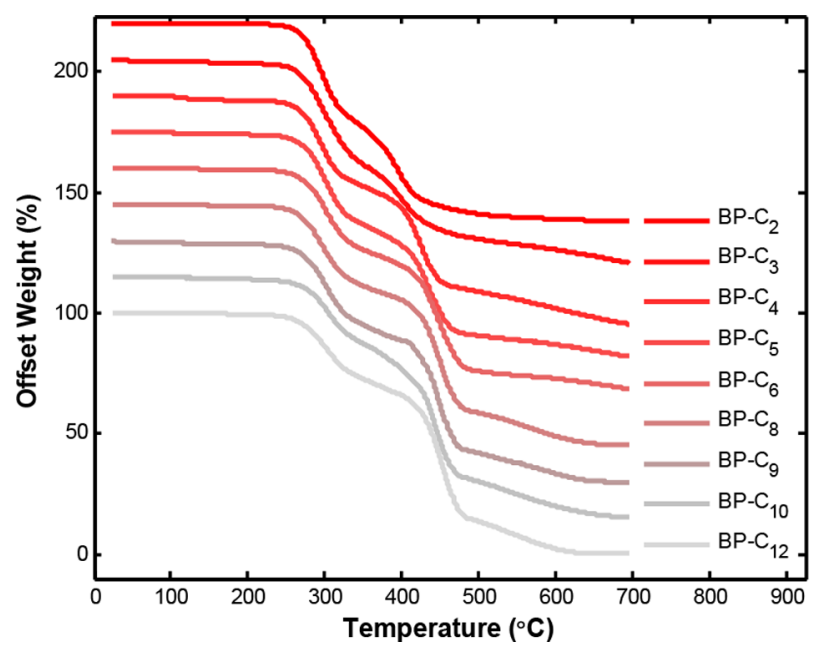

Figure 2. Offset TGA thermograms depicting the thermal stability of the various $\mathrm{BP}-\mathrm{C}_{x}$ monomers developed in this study. The applied heating rate for the TGA experiments was $10{ }^{\circ} \mathrm{C} / \mathrm{min}$.

monomers, and no significant weight loss is detected below $250{ }^{\circ} \mathrm{C}$. With respect to the thermal transitions prior to degradation, the BP- $\mathrm{C}_{x}$ monomers display distinct melting behavior $\left(T_{\mathrm{m}}\right)$ during the first heating run in DSC analysis. During the second DSC heating run, cold-crystallization and consecutive melting are observed only for the BP- $\mathrm{C}_{2}, \mathrm{BP}_{-} \mathrm{C}_{8}$, and $\mathrm{BP}_{-} \mathrm{C}_{12}$ monomers, as is displayed in Figure $3 \mathrm{~A}$ for $\mathrm{BP}_{-} \mathrm{C}_{8}$. All other monomers do not crystallize within the time provided by the DSC analysis methods, but instead display a characteristic glass transition temperature $\left(T_{\mathrm{g}}\right)$. The presence of such a $T_{\mathrm{g}}$ likely originates from the hydrogen bonding between dicarboxylic acid groups, resulting in long-range order. Indeed, this seems to be the case as the $T_{\mathrm{g}}$ of the $\mathrm{BP}-\mathrm{C}_{x}$ monomers (Figure $3 \mathrm{~B}$ ) decreases rather linearly with the hydrogen bonding density of the carboxylic acid groups, as is explained in the Supporting Information.

An overview of all the peak melting temperatures observed during the first heating run and the glass transition temperatures observed during the second heating run is depicted in Figure 3B. In general, the melting temperature of the $\mathrm{BP}-\mathrm{C}_{x}$ monomers decreases with increasing methylene spacer length. For example, the $\mathrm{BP}-\mathrm{C}_{2}$ monomer exhibits a peak melting temperature at 238 ${ }^{\circ} \mathrm{C}$, whereas the $\mathrm{BP}-\mathrm{C}_{12}$ monomer melts already at $145{ }^{\circ} \mathrm{C}$. Additionally, a characteristic odd-even effect ${ }^{62,63}$ is observed: The BP- $\mathrm{C}_{x}$ monomers with an odd amine spacer are displaying significantly lowered melting temperatures compared to those of the $\mathrm{BP}-\mathrm{C}_{x}$ monomers containing even diamine spacers. This low melting temperature of $\mathrm{BP}^{-\mathrm{C}_{x}}$ monomers with odd amine spacers explains their previously observed low isolated yield: BP$\mathrm{C}_{x}$ monomers with odd amine spacers can only form crystallites with defects and thus low melting temperatures during recrystallization from solvent. As a consequence, crystal growth is significantly hindered, thereby lowering the isolated yield after recrystallization.

Overall, on the basis of the synthesis procedure and the behavior of the synthesized BP- $\mathrm{C}_{x}$ monomers, we can conclude that the modified bulk synthesis allows for upscaling in good yield when using diamine spacers that generate high melting BP$\mathrm{C}_{x}$ monomers.

Curing Performance of BP- $\mathrm{C}_{x}$ Monomer in 2-Oxazoline Resins. The $\mathrm{BP}_{-} \mathrm{C}_{x}$ monomers were used as dicarboxylic acid for the preparation of 2-oxazoline resins. To avoid the use of 

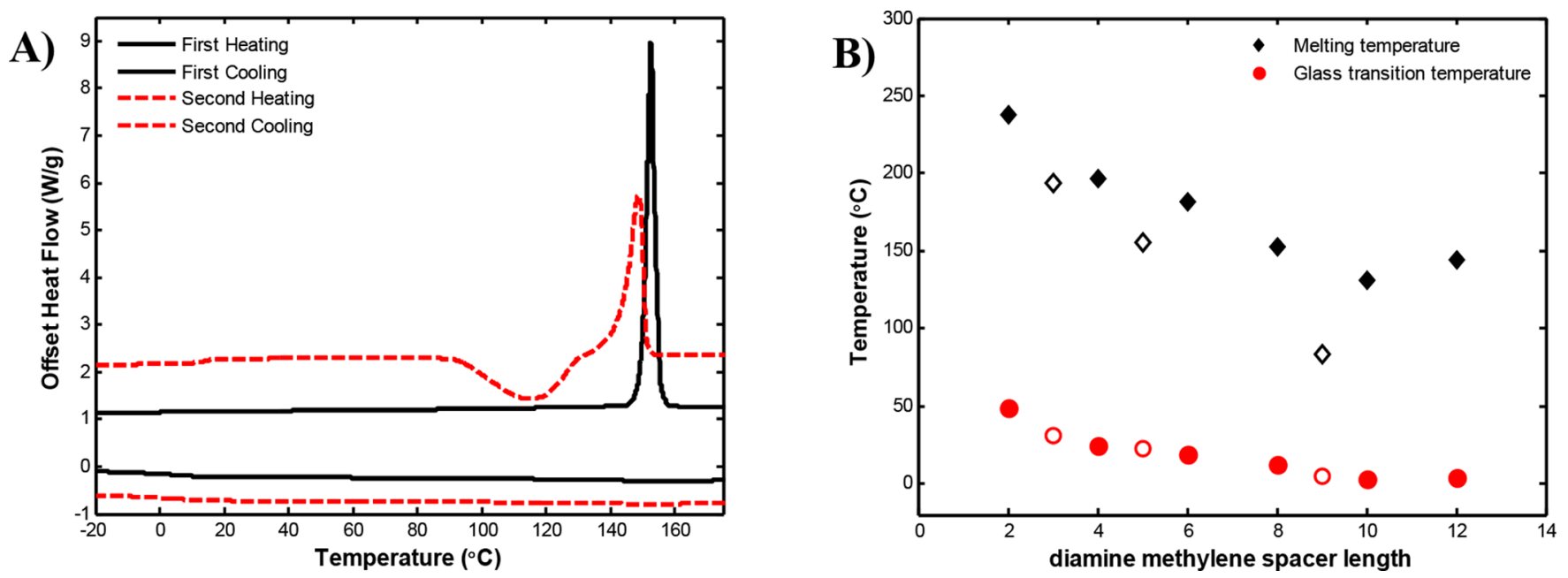

Figure 3. (A) DSC thermogram of BP- $\mathrm{C}_{8}$ depicting the characteristic melting behavior of purified BP-C $\mathrm{x}_{x}$ monomers. (B) Overview of the peak melting temperatures of the synthesized monomers observed during the first DSC heating run, and the glass transition temperature observed during the second DSC heating run. All heating and cooling rates were $10{ }^{\circ} \mathrm{C} / \mathrm{min}$. Note that the filled symbols depict the thermal transitions of the $\mathrm{BP}-\mathrm{C}_{x}$ monomers containing even amine spacers, whereas the open symbols depict the thermal transitions of the BP- $\mathrm{C}_{x}$ monomers with odd amine spacers.

solvents, the monomers were ground in the solid state and polymerized in bulk. In this study, the evaluated bis(2-oxazoline) monomers are 1,3-bis(4,5-dihydrooxazol- 2-yl)benzene (IAox) and the renewable 2,5-bis(4,5-dihydrooxazol-2-yl)furan (FDCAox). An overview of the used monomers for polymerization reactions is provided in Scheme 3. The characteristic

Scheme 3. Overview of the Used Monomers for Polymerization Reactions Performed in This Study<smiles>O=C(O)OCc1ccc(C2=NCCO2)o1</smiles><smiles>[X][R4]#[X]</smiles><smiles>[Y]C(Br)(Br)C(=O)O</smiles><smiles>CC(CCC(=O)O)C(=O)O</smiles>

polymerization reaction of $\mathrm{BP}^{-\mathrm{C}_{x}}$ monomers with FDCAox is depicted in Scheme 1. In general, the ring-opening polyaddition reaction between dicarboxylic acids and bis(2-oxazoline)s $\left(k_{1}\right)$ yields linear poly(ester-amide)s. ${ }^{57}$ However, the formed amide bond is susceptible to reaction with another 2-oxazoline moiety $\left(k_{2}\right)$, thereby providing the means to generate branched or crosslinked structures. In previous work we have demonstrated that the branching and cross-linking reaction is highly dependent on the selected bis(2-oxazoline spacer): To recall, the amorphous 2,5-furandicarboxylic acid based amide groups are highly susceptible to participation in a branching reaction with a 2oxazoline. $^{57}$

The curing performance of the $\mathrm{BP}-\mathrm{C}_{x}$ monomers in 2oxazoline resins was tested in equimolar systems containing either FDCAox or IAox. As reference, the reaction with sebacic acid as aliphatic dicarboxylic acid was performed. The equimolar systems were cured for $1 \mathrm{~h}$ at $180{ }^{\circ} \mathrm{C}$ under a nitrogen atmosphere. The conversion and molecular weights were determined through ${ }^{1} \mathrm{H}$ NMR and GPC analysis of samples taken at regular time intervals. The conversion determination procedure from NMR analysis and representative NMR spectra are provided in the Supporting Information. Figure 4 depicts the

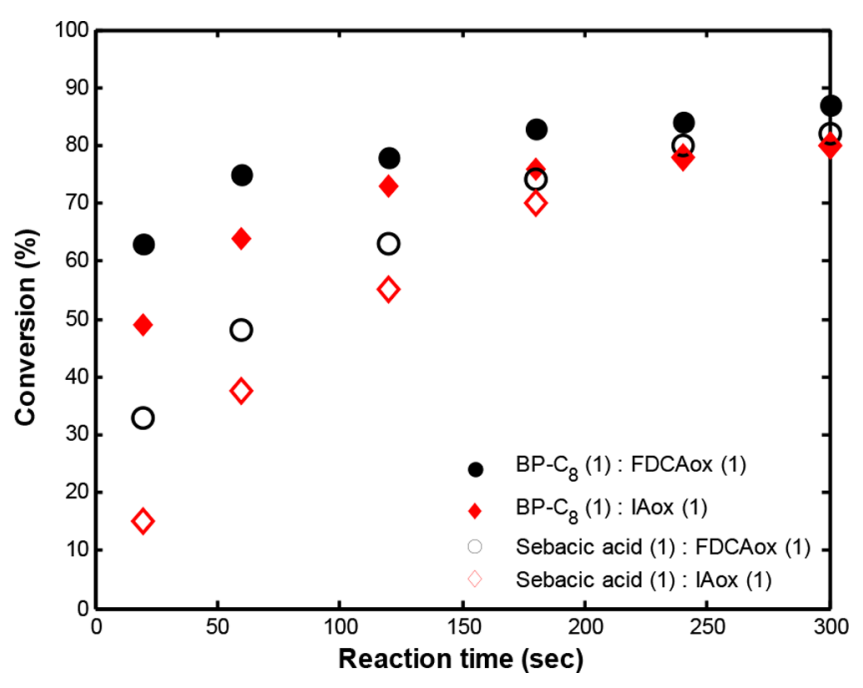

Figure 4. Conversion calculated from NMR analysis during the first 5 $\mathrm{min}$ of curing of the various 2 -oxazoline resins at $180^{\circ} \mathrm{C}$. Characteristic NMR spectra and calculation method are provided in the Supporting Information.

conversion over time for the first $5 \mathrm{~min}$ of reaction time for the tested reaction systems: In general we observe that all systems go to roughly $90 \%$ conversion within this reaction time. Such a high reactivity is expected as the reaction of 2-oxazolines with dicarboxylic acids is known to proceed sufficiently fast at this reaction temperature to allow for chain-extension reactions in compounding or extrusion processes. Interestingly, we observe that resins with $\mathrm{BP}_{-} \mathrm{C}_{8}$ react significantly faster compared to systems containing sebacic acid as they already achieve more than $50 \%$ conversion within $20 \mathrm{~s}$ of reaction time. Additionally, as reported in previous work, resins containing 2,5-FDCAox exhibit a higher reactivity than systems containing IAox (Figure 4), which is attributed to the increased tendency of FDCAox to undergo cross-linking with the formed amide groups. ${ }^{57}$ 

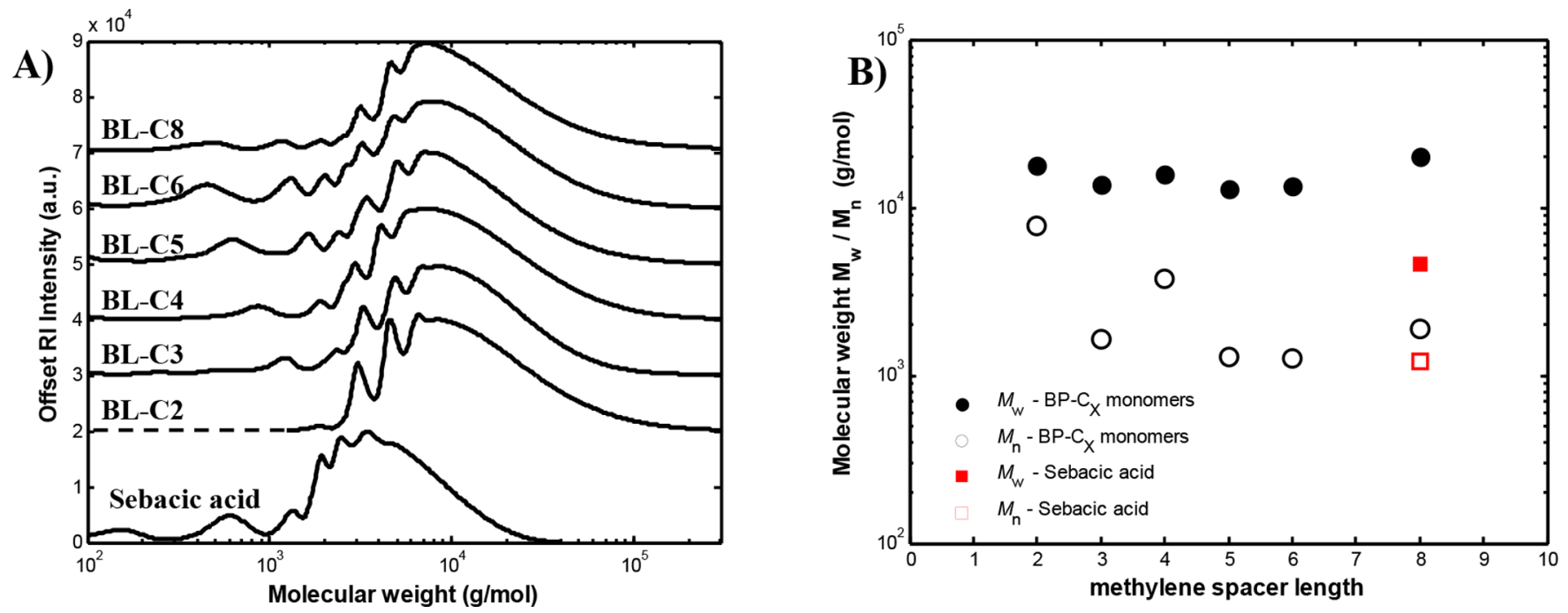

Figure 5. (A) GPC traces of equimolar systems containing dicarboxylic acid and IAox cured for 1 min at $180{ }^{\circ} \mathrm{C}$. (B) Overview of corresponding molecular weights $\left(M_{\mathrm{w}}\right.$ and $\left.M_{\mathrm{n}}\right)$ of the GPC traces shown in Figure 6A.
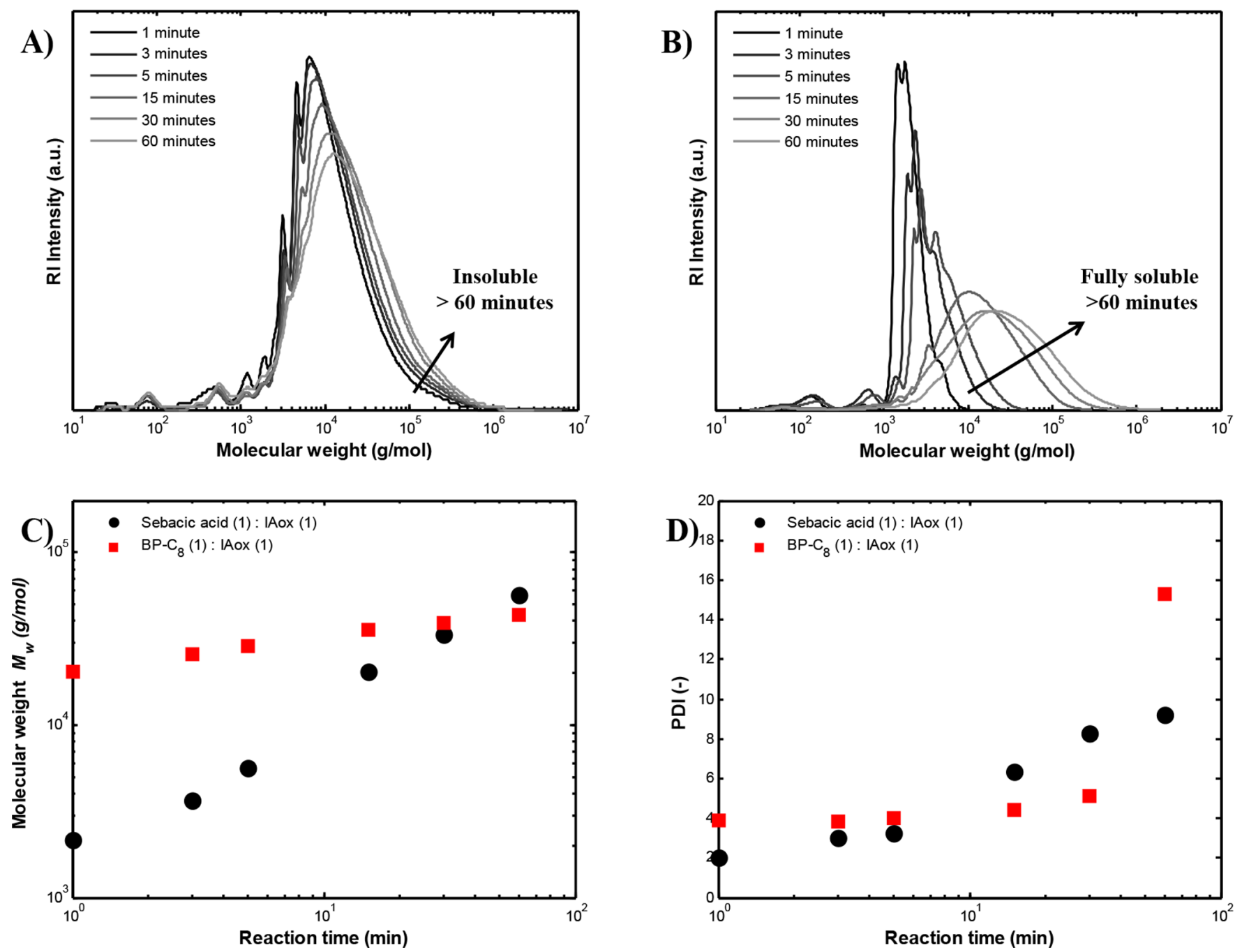

Figure 6. Molecular weight build-up according to GPC analysis during curing at $180^{\circ} \mathrm{C}$ for an equimolar (A) BP-C 8 :IAox and (B) sebacic acid:IAox resin. Parts $\mathrm{C}$ and D depict the increase in $M_{\mathrm{w}}$ and PDI over time, respectively, for both systems.

To obtain more information on the molecular weight build-up at the start of the curing process, systems containing various $\mathrm{BP}$ -
$\mathrm{C}_{x}$ monomers and IAox have been cured for $1 \mathrm{~min}$ at $180^{\circ} \mathrm{C}$, and their molecular weights were evaluated through HFIP-GPC 
A)

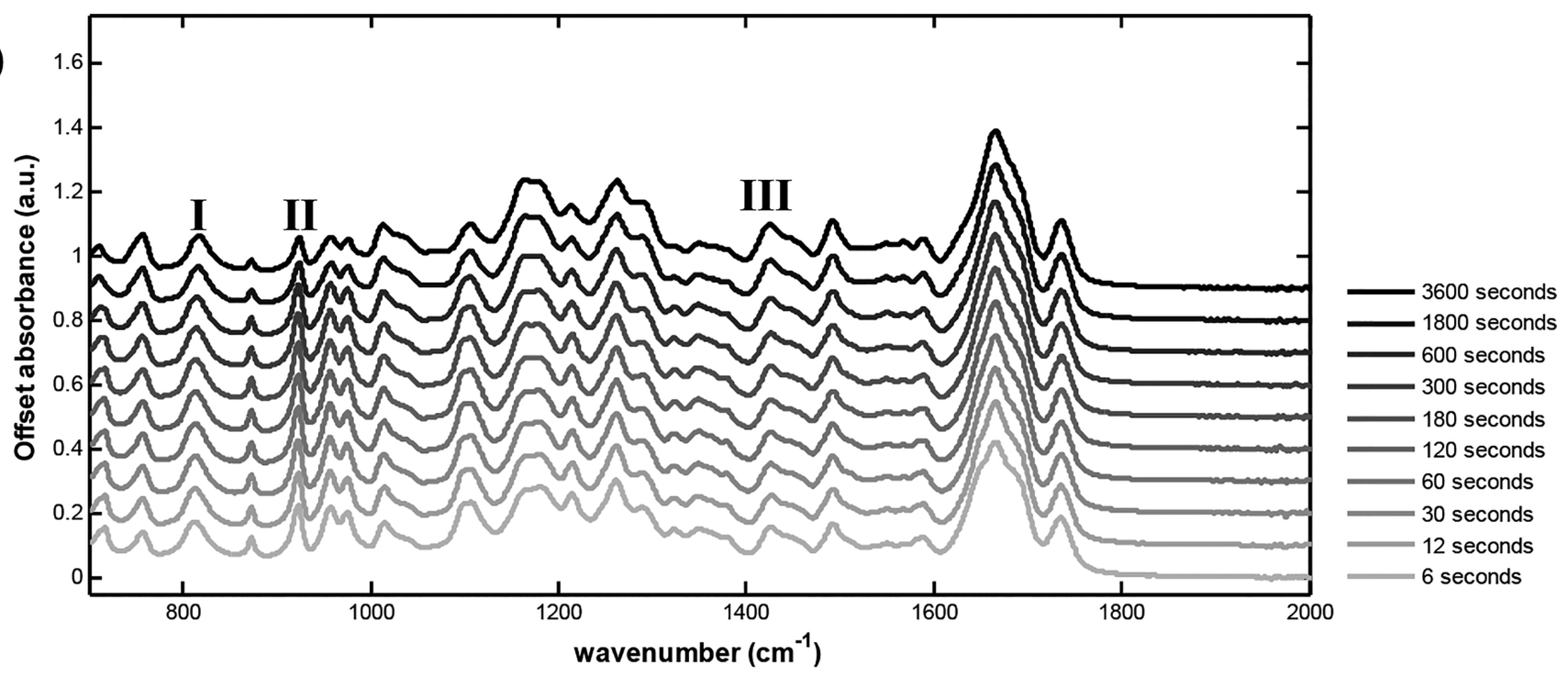

B)
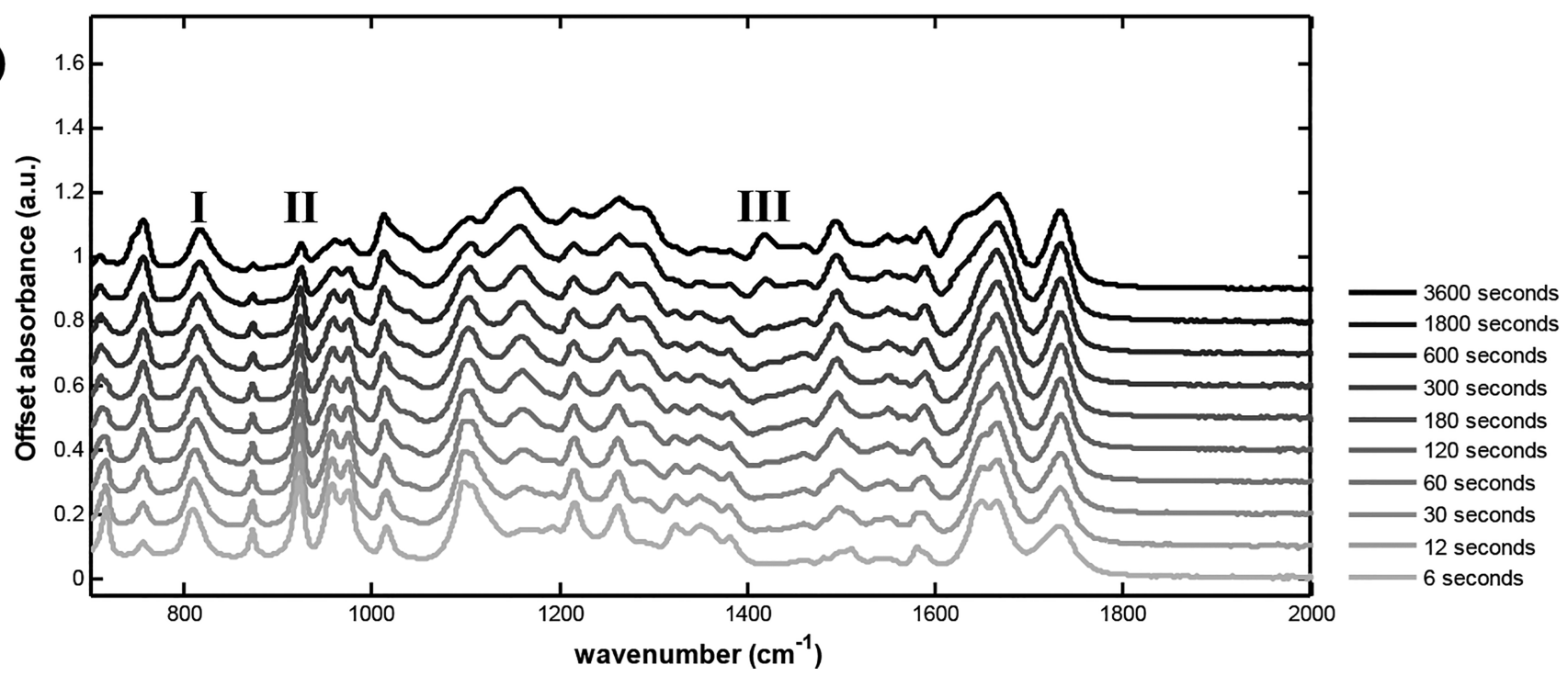

Figure 7. FTIR spectra $\left(700-2000 \mathrm{~cm}^{-1}\right)$ obtained during the online monitoring of the curing of (A) BP-C C $_{8}$ FDCAox and (B) sebacic acid:FDCAox systems at $180{ }^{\circ} \mathrm{C}$. Both polymerizations were performed in a dicarboxylic acid:2-oxazoline ratio of 1:2. Vibrational bands I, II, and III denote the characteristic vibrations from the furan ring, 2-oxazoline ring, and tertiary amide bonds, respectively.

analysis. Please note that we confine ourselves to IAox based systems for the determination of molecular weights given the high tendency of FDCAox based resins to undergo rapid crosslinking, thereby limiting their solubility. As is visible from Figure 5 , the molecular weights $\left(M_{\mathrm{w}}\right)$ of the systems containing the BP$\mathrm{C}_{x}$ monomers reach $10-20 \mathrm{~kg} / \mathrm{mol}$ within only $1 \mathrm{~min}$ of curing. In contrast, the system containing sebacic acid only yields a $M_{w}$ of $4.5 \mathrm{~kg} / \mathrm{mol}$ after the same reaction time. Additionally, the presence of monomers and oligomers can be detected in the GPC traces of all systems, confirming that no full conversion is yet achieved (Figure 5A). Furthermore, in all BP-C $\mathrm{C}_{x}$ GPC traces a high molecular weight tail is observed, likely indicating the presence of branched structures.

To obtain more information on the polymerization proceeding over time, the IAox based resins containing sebacic acid and BP- $\mathrm{C}_{8}$ were cured for $1 \mathrm{~h}$, and their molecular weight build-up was monitored over time using GPC analysis. As is shown in the GPC traces of the IAox:BP-C $\mathrm{C}_{8}$ resin (Figure 6A), a rapid molecular weight build-up is achieved immediately upon melting.
Over time, the residual monomers and oligomers continue to react, and the high molecular weight tail increases, but overall, no significant changes are observed in the GPC traces. This experiment confirms that systems with $\mathrm{BP}-\mathrm{C}_{8}$ exhibit extremely high reactivity and rapidly build up molecular weight. Furthermore, after $60 \mathrm{~min}$ of curing, the sample proved to be only partially insoluble in the HFIP solvent, indicating that branching and cross-linking proceed over time.

In contrast, when looking at the GPC traces of the sebacic acid based resin (Figure 6B), we observe a more gradual increase in molecular weight over time. Such behavior is characteristic for the polycondensation type of polymerizations. Additionally, when the polymerization reaches high conversions, an increase in high molecular weight tail and $M_{\mathrm{w}}$ is observed together with a systematic increase in dispersity, indicating that branching also occurs in this system (Figure 6C,D). That being said, branching and cross-linking proceed significantly more slowly in the presence of sebacic acid compared to samples containing $\mathrm{BP}^{-\mathrm{C}_{8}}$ 

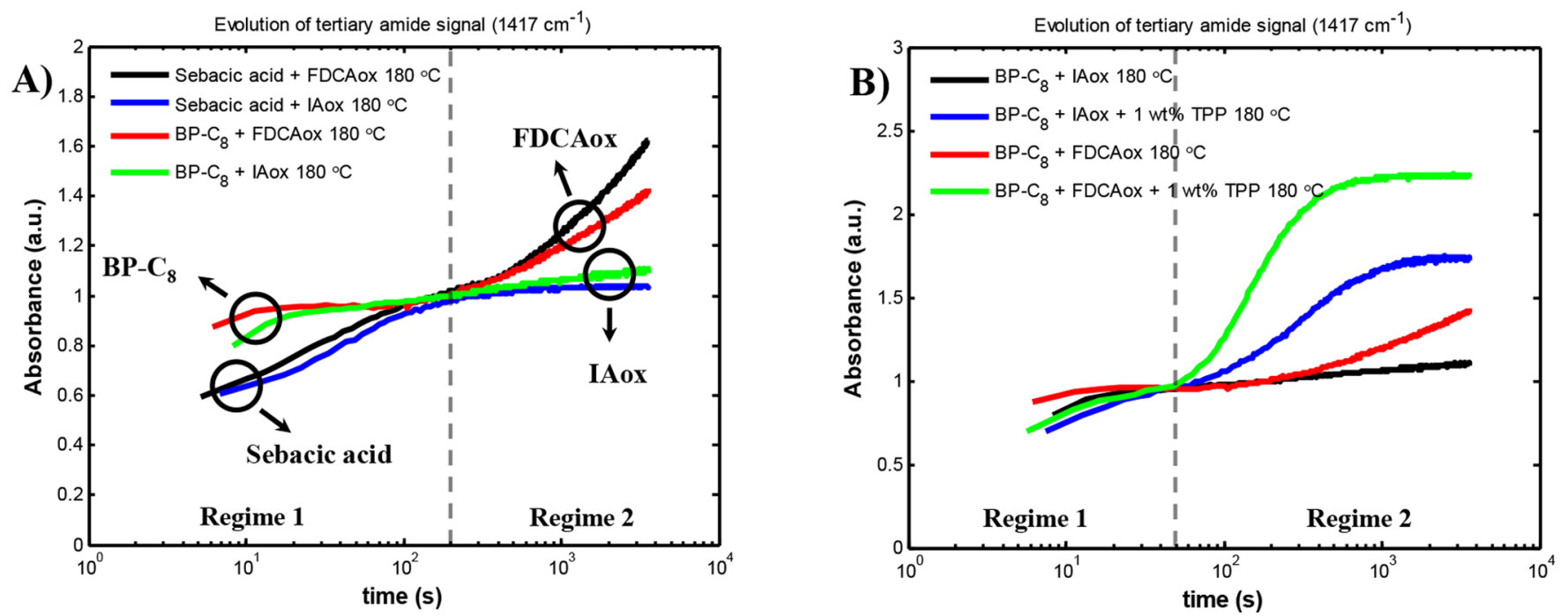

Figure 8. Changes of the normalized tertiary amide vibration III during polymerization of dicarboxylic acid:bis(2-oxazoline) resins (ratio of 1:2) at 180 ${ }^{\circ} \mathrm{C}$. The curves are freely shifted vertically to align the plateau values obtained at the end of regime 1 to ease the comparison.

as the system remains fully soluble in HFIP, even after $6 \mathrm{~h}$ of reaction time.

From previous observations we have strong indications that the $\mathrm{BP}-\mathrm{C}_{x}$ monomers significantly enhance the reaction rate of 2 oxazoline resins compared to aliphatic dicarboxylic acids. However, at this point it is not clear whether the presence of $\mathrm{BP}-\mathrm{C}_{x}$ selectively accelerates the $k_{1}$ (chain extension) or $k_{2}$ (branching) reaction constant as both processes seem to proceed simultaneously. In order to gain more information on this reactivity difference, online monitoring of the polymerization is performed using ATR-FTIR analysis. For these reactions a carboxylic acid:2-oxazoline ratio of 1:2 has been used to enforce cross-linking and to assess the $k_{2}$ reaction constant: The excess of 2-oxazoline moieties ensures a rapid conversion of the dicarboxylic acids into ester-amide bonds in the initial stage of polymerization, leaving the residual 2-oxazoline moieties only with the amide groups to react. The reaction of the 2-oxazoline moiety with the secondary amide yields a tertiary amide bond (Scheme 1), which exhibits a characteristic resonance in FTIR spectroscopy around $1417 \mathrm{~cm}^{-1}$. Figure 7A,B depicts the characteristic FTIR spectra obtained during a polymerization of FDCAox based resins containing $\mathrm{BP}-\mathrm{C}_{8}$ and sebacic acid as dicarboxylic acid, respectively. The FTIR spectra obtained during polymerization of systems containing IAox as bis(2-oxazoline) are provided in the Supporting Information. Three distinct vibrational bands are highlighted in Figure 7: I corresponds to the furan ring vibration $\left(816 \mathrm{~cm}^{-1}\right)$, II corresponds to the 2oxazoline ring vibration $\left(922 \mathrm{~cm}^{-1}\right)$, and III corresponds to the tertiary amide bonds vibration $\left(1412 \mathrm{~cm}^{-1}\right)$. In general for both systems we observe that peak area I remains constant during the curing process, indicating that no evaporation of the FDCAox occurs over time. The fact that no components are evaporating over time allow us to use this vibration as internal standard. Signals II and III change over time as a result of the proceeding chemical reaction, as the 2-oxazoline ring is depleted during ringopening (signal II) and tertiary amide bonds are formed upon cross-linking (signal III).

When qualitatively comparing the change in tertiary amide bond signal (III) over time for the four tested systems, we can identify two characteristic regimes in the polymerization (Figure 8 ). Regime 1 denotes the region where most melting of the mixture proceeds in combination with reaction of the 2-oxazoline moieties with carboxylic acid groups until a plateau value is observed. According to the NMR analysis depicted in Figure 4, this generally proceeds within the first minutes of polymerization. Regime 2 denotes the region where the remaining 2oxazolines react with the generated amide bonds; hence, the cross-linking of the system is proceeding. Obviously, these regimes differ per reaction and depend on temperature, reaction rate, and the presence of a catalyst. For this reason, nonindicative lines separating the two regimes are added to guide the eye.

Interestingly, systems containing $\mathrm{BP}-\mathrm{C}_{8}$ tend to melt rapidly and reach a plateau value within seconds, as is visible from Figure $8 \mathrm{~A}$. However, the cross-linking of the reaction mixtures seems to depend mostly on the selected bis(2-oxazoline) spacer, as only the systems containing FDCAox tend to rapidly cross-link over time. Systems containing IAox do exhibit cross-linking, but at a significantly decreased rate compared to those of FDCAox based systems. The addition of triphenyl phosphite (TPP) as catalyst does facilitate the cross-linking reaction for all systems (Figure $8 \mathrm{~B}$ ), indicating that the $k_{2}$ reaction constant is determined by either the selected bis(2-oxazoline) or catalyst, but not by the dicarboxylic acid. The FTIR spectra obtained during polymerization of systems containing $1 \mathrm{wt} \%$ TPP used for the generation of Figure $8 \mathrm{~B}$ are provided in the Supporting Information.

To obtain quantitative insight on the effect of BP-C monomers on the polymerization kinetics, data fitting using normalized resonance II (2-oxazoline ring vibration) as input has been performed for the systems containing FDCAox. The reaction kinetics of the polymerization between bis(2oxazoline)s and dicarboxylic acids can be described using differential equations (eqs 1-3):

$$
\begin{aligned}
& \frac{\delta[\text { acid }]}{\delta \mathrm{t}}=-\frac{\delta[\text { ester }]}{\delta \mathrm{t}}=-\frac{\delta[\mathrm{sec} \text { amide }]}{\delta \mathrm{t}} \\
& =-k_{1}[\text { acid }][\mathrm{OX}] \\
& \frac{\delta[\mathrm{OX}]}{\delta t}=-k_{1}[\text { acid }][\mathrm{OX}]-k_{2}[\mathrm{sec} \text { amide }][\mathrm{OX}] \\
& \frac{\delta[\text { tert amide }]}{\delta t}=k_{2}[\mathrm{sec} \text { amide }][\mathrm{OX}]
\end{aligned}
$$


Sebacic acid (1): FDCAox (2) reaction at $180^{\circ} \mathrm{C}$

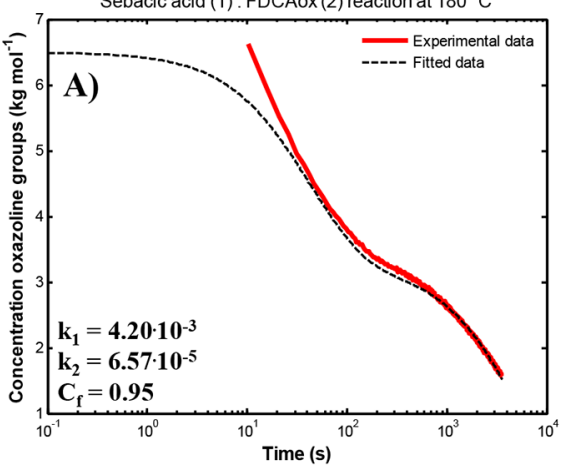

BP-C8 (1) : FDCAox (2) reaction at $180^{\circ} \mathrm{C}$

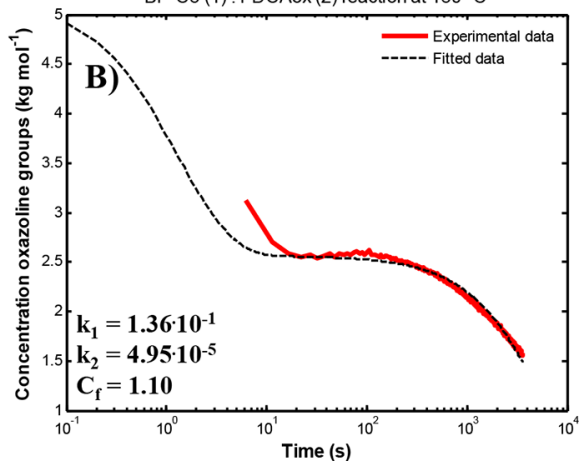

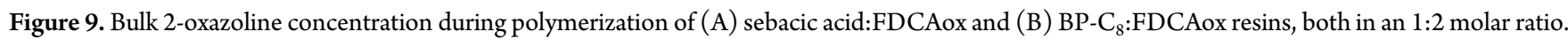
The red line indicates the experimental data, whereas the black dotted line corresponds to the obtained fit. $C_{\mathrm{f}}$ indicates the conversion factor.
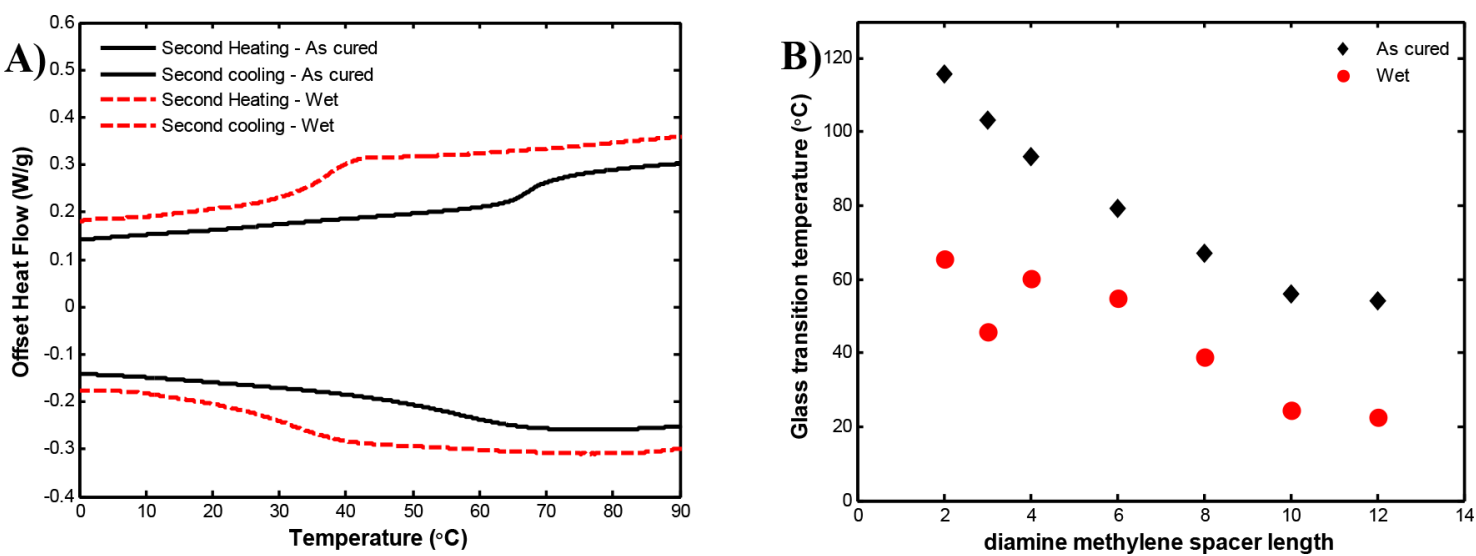

Figure 10. (A) Second DSC heating and cooling traces for FDCAox:BP- $\mathrm{C}_{8}$ systems cured in an equimolar ratio at $180{ }^{\circ} \mathrm{C}$. The same film has been measured directly after curing and after exposure to air. Image $\mathrm{B}$ depicts the glass transition before and after air exposure for cured films containing various $\mathrm{BP}_{-} \mathrm{C}_{x}$ monomers and FDCAox. All DSC runs were performed at heating and cooling rates of $10{ }^{\circ} \mathrm{C} / \mathrm{min}$.

In differential equations (eqs $1-3$ ), the 2-oxazoline concentration is denoted as $[\mathrm{OX}]$ in $\mathrm{mol} / \mathrm{kg}$. Similarly, the concentrations of the ester groups, amide groups, and tertiary amide groups are denoted as [ester], [sec amide], and [tert amide], respectively (in $\mathrm{mol} / \mathrm{kg}$ ). After normalization of the area of resonance II by the area of resonance I, followed by conversion to concentration using a conversion factor, ${ }^{57}$ the 2 -oxazoline concentration during polymerization is obtained. This data has been used as input to fit both $k_{1}$ and $k_{2}$ reaction constants using differential equations (eqs 1-3, Figure 9). For the data fitting we assumed that both reactions are second order and irreversible, and that both 2-oxazoline moieties in a bis(2-oxazoline) reactant are equireactive. ${ }^{52}$ Additionally, we assumed that the 2 -oxazoline concentration is linearly dependent on the normalized resonance II peak area, thus ignoring contributions from potential evaporation or changes in density during polymerization. ${ }^{57}$

From Figure 9 we can observe that the method used can fit the FTIR data rather well. Remarkably, the $k_{2}$ reaction constants of the two different resins are at the same order of magnitude, while the $k_{1}$ reaction constant increases with more than 1 order of magnitude when exchanging sebacic acid for $B P-C_{8}$. These findings indicate that the previously observed enhancement in reaction and cross-linking rate in $\mathrm{BP}_{-} \mathrm{C}_{8}$ based systems can be attributed to the selective enhancement of the $k_{1}$ reaction constant only. The predicted molecular weight build-up during curing and the resulting decrease in cross-linking time as a function of the change in $k_{1}$ reaction constant is provided in the Supporting Information.
Please note, for the system containing $B P-C_{8}$, we expect that the $k_{1}$ reaction constant obtained from the fit depicted in Figure 9 is overestimated. This is a result from the rapid 2-oxazoline depletion immediately upon the melting of the mixture, thereby preventing the collection of sufficient data points, and at early stage of the polymerization. Nevertheless, despite the potential error in the $k_{1}$ value, we can clearly observe that the $k_{1}$ constant is significantly higher when using $\mathrm{BP}_{-} \mathrm{C}_{8}$ as dicarboxylic acid. This behavior is consistently observed in systems containing other BP$\mathrm{C}_{x}$ monomers as is shown in the Supporting Information.

The observed enhancement in $k_{1}$ reaction constant in this work is rather comparable to the findings reported by Néry and co-workers for systems using a pyridine based bis(2-oxazoline). These authors attributed the enhanced reactivity to $(1)$ the basic nature of the pyridine ring and (2) to the stabilization of the protonated 2-oxazoline moiety. ${ }^{52}$ Given the basic but nonreactive nature of $\mathrm{N}$-alkylated pyrrolidone moieties, it is plausible that they promote the deprotonation of the carboxylic acid moiety and thereby enhance its reactivity toward electrophiles such as 2-oxazolines. Verification of this hypothesis is part of ongoing work and will be communicated in future publications.

Thermal Behavior of the Developed Thermosets. With an understanding of the effect of $\mathrm{BP}-\mathrm{C}_{x}$ monomers on the curing kinetics in 2-oxazoline resins, in this section we evaluate their effect on the thermal behavior of the fully renewable thermosets, being systems based on FDCAox. To this end, various resins containing FDCAox and several readily recrystallizable $\mathrm{BP}_{-} \mathrm{C}_{x}$ monomers have been prepared in an equimolar ratio and were 
Scheme 4. Overview of the Reference Compounds and the Used TNBS Sodium Salt Indicator Used To Identify UV Activity and the Presence of Amines in the Degradation Products<smiles>O=C(NCCO)c1ccc(C(=O)NCCO)o1</smiles>

$N^{2}, N^{5}$-bis(2-hydroxyethyl)furan-2,5-dicarboxamide (BHFDA)<smiles>O=[N+]([O-])c1cc([N+](=O)[O-])c(S(=O)(=O)[O-])c([N+](=O)[O-])c1</smiles>

2,4,6-trinitrobenzenesulphonic acid (TNBS)<smiles>O=C(O)C1CC(=O)N(CCCCCCCCN2CC(C(=O)O)CC2=O)C1</smiles>

N,N'-octamethylene-bis(pyrrolidone-4-carboxylic acid) BP-C 8<smiles>NC(CO)(CO)CO</smiles>

tris(hydroxymethyl)aminomethane (tris)

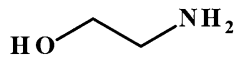

Ethanolamine

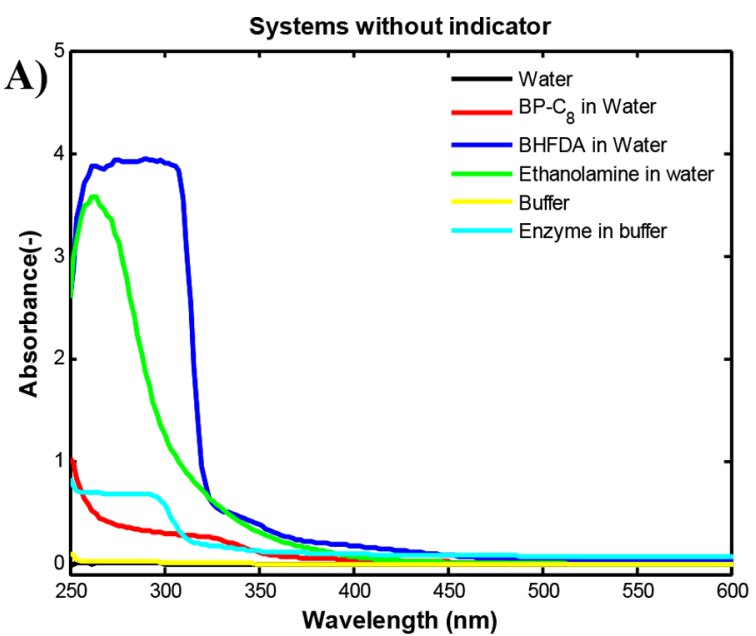

FDCAOx:BP-C $\mathrm{B}_{8}(1: 1)$ systems without indicator

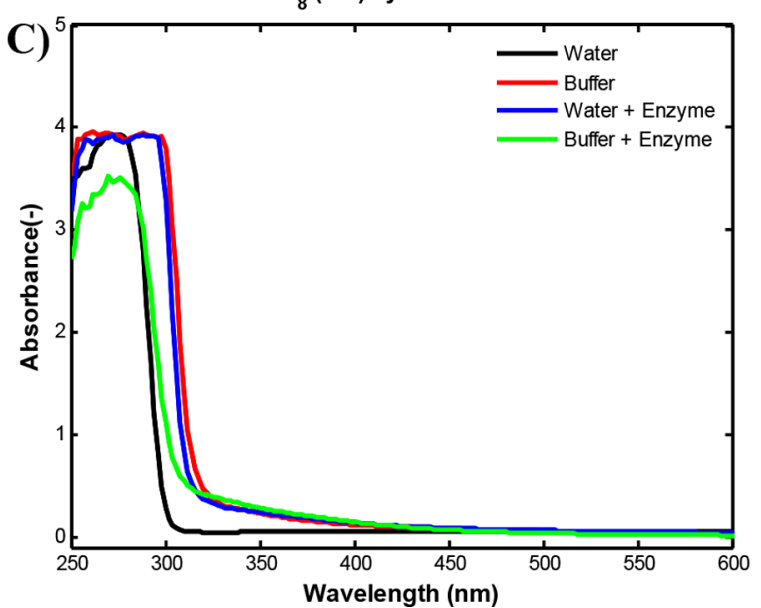

Systems with TNBS indicator

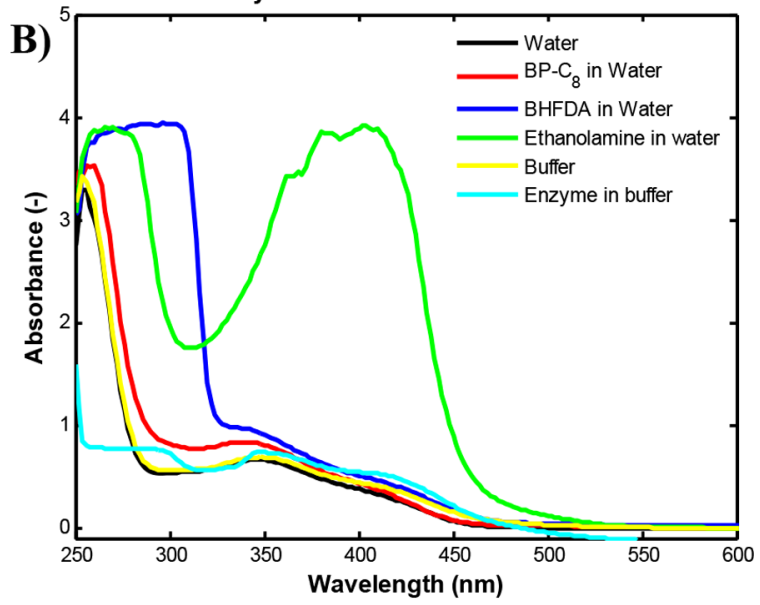

FDCAox:BP-C ${ }_{8}(1: 1)$ systems with TNBS

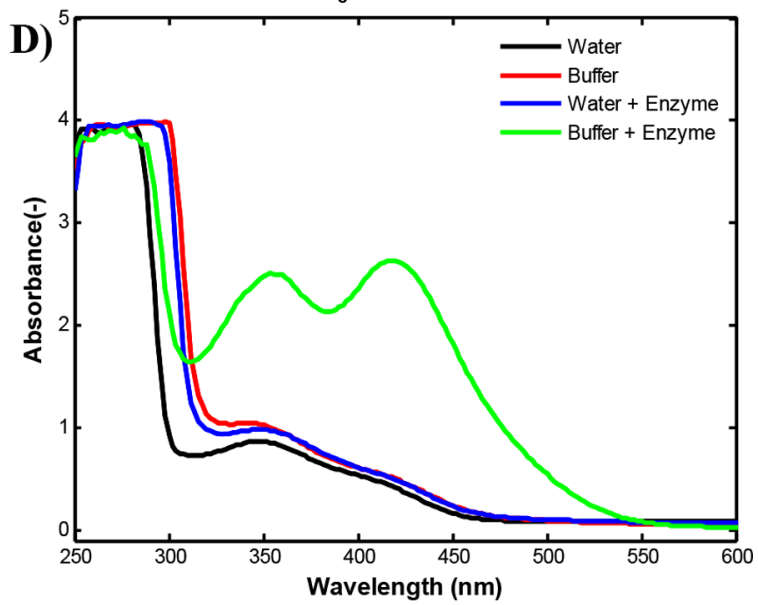

Figure 11. UV absorbance of solutions containing various media in the range 250-600 nm without (A, C) and with (B, D) TNBS as indicator.

cured for $1 \mathrm{~h}$ at $180^{\circ} \mathrm{C}$ in the absence of catalyst. The obtained materials were analyzed for their thermal transitions using DSC analysis. The obtained materials are all amorphous in nature, as can be observed from the exemplary DSC heating and cooling traces for the FDCAox:BP-C $\mathrm{C}_{8}$ based thermoset (Figure 10A). As expected, the rigid nature of the pyrrolidone rings in the polymer 
backbone increases the $T_{\mathrm{g}}\left(70{ }^{\circ} \mathrm{C}\right.$ for $\left.\mathrm{BP}-\mathrm{C}_{8}\right)$ compared to the thermosets based on sebacic acid $\left(52{ }^{\circ} \mathrm{C}\right)$. Furthermore, also in line with expectations, the $T_{\mathrm{g}}$ of the thermoset increases with a decreasing number of methylene spacers of the used BP-C monomer (Figure 10B).

One particular point for attention in these amorphous materials is that the presence of numerous free electron pairs in the oxygen and nitrogen atoms results in the significant absorption of water: As is visible from Figure 10A, exposure to water or moisture results in a plasticizing effect, thereby decreasing the glass transition temperature by roughly $30^{\circ} \mathrm{C}$. Such amorphous behavior combined with the plasticizing effect of water is observed for all FDCAox:BP-C ${ }_{x}$ based thermosets, as is shown in Figure 10B. The introduction of water as plasticizer improves the deformability of the thermoset, but can also result in rapid hydrolysis of the ester groups present in these poly(esteramide)s. ${ }^{1,17,54}$ Though such hydrolysis can hamper the structural integrity and lifetime of the materials, it also opens up possibilities for depolymerization and biodegradation of the thermosets.

To identify whether such depolymerization occurs in the presence of water, preliminary degradation studies were performed: In general, $30 \mathrm{mg}$ of product was placed in $1 \mathrm{~mL}$ of demineralized water or tris(hydroxymethyl)aminomethane (tris) buffer (100 mM, pH 8). Optionally, protease enzyme from Bacillus $\mathrm{Sp}^{58}$ (0.8 mL, 16 units/mL, Sigma-Aldrich) was added together with $200 \mu \mathrm{L}$ of $0.01 \mathrm{M} \mathrm{CaCl}_{2}$ solution. Please note that this enzyme is commonly present in soil and is generally responsible for the breakdown of amide bonds. Next, the vials were sealed and incubated for $72 \mathrm{~h}$ at $50{ }^{\circ} \mathrm{C}$ under constant shaking.

After incubation, the solutions were placed in a cuvette and analyzed using UV-vis spectrophotometry, together with a series of model compounds expected to form after hydrolysis of the ester bonds in the FDCAox:BP-C ${ }_{8}(1: 1)$ polymers (Scheme 4). Directly after UV-vis analysis of the mixtures, $25 \mu \mathrm{L}$ of a $1 \mathrm{wt}$ $\%$ solution of 1,4,6-trinitrobenzenesulfonic acid (TNBS) sodium salt was added, mixed with a pipet, and placed back for UV-vis analysis. TNBS is a well-known indicator for primary amines $^{64-68}$ which allows us to identify whether the used protease facilitates amide bond breakage. In general, TNBS (absorption maximum at 250-260 nm) reacts with primary amines to form a Meisenheimer complex (absorption maximum at $420 \mathrm{~nm}$ ), which in turn can react further into a trinitrophenylamine (absorption maximum at $340 \mathrm{~nm}$ ). ${ }^{69}$ In the absence of amines, partial hydrolysis of TNBS occurs yielding picric acid which displays an absorption maximum at $340 \mathrm{~nm} .{ }^{65}$ Figure 11 displays the UV-vis spectra in the range between 250 and 600 $\mathrm{nm}$ for the various mixtures evaluated in this study.

In general we can observe from Figure 11A that both pure water and tris buffer do not absorb UV light in the evaluated range 250-600 $\mathrm{nm}$. BHFDA, the compound expected to be formed after hydrolysis of the ester bonds in FDCAox based thermosets (Scheme 4), does display a strong absorption peak around $280 \mathrm{~nm}$. The other hydrolysis product, $\mathrm{BP}-\mathrm{C}_{8}$, displays a minor absorption peak below $320 \mathrm{~nm}$. Ethanolamine, a reaction product expected to be formed after hydrolysis of the furandicarboxamide bonds displays an adsorption maximum at $260 \mathrm{~nm}$. Lastly, we observe also that the enzyme does not interfere with the TNBS activity as it only displays an absorption maximum below $300 \mathrm{~nm}$.

As expected, the addition of TNBS to water only results in hydrolysis of the TNBS resulting in UV absorption correspond- ing to the presence of picric acid (Figure 11B). Similarly, addition of TNBS to BP-C ${ }_{8}, \mathrm{BHFDA}$, and the enzyme solutions only results in partial hydrolysis of TNBS. Please note that, in addition, tris buffer does not interact with TNBS in our used detection protocol despite the presence of an amine group, which is likely a result from steric hindrance of the three bulky ethanol side groups. In contrast, the system containing ethanolamine rapidly changes color when TNBS is added and displays a dominant UV absorption at $420 \mathrm{~nm}$, indicating the presence of the Meisenheimer complex (in fact, the UV absorption at this concentration is close to the detection limit).

Systems containing FDCAox and $\mathrm{BP}_{-} \mathrm{C}_{8}$ based thermosets (1:1 ratio) were also incubated under various conditions. The general observations from these studies are that the presence of water alone is not sufficient to depolymerize the material: The thermosets immersed in water only swell but do not fully dissolve within a period of several weeks. In contrast, immersion in the slightly alkaline buffer does result in swelling and dissolution of the thermoset within $72 \mathrm{~h}$. Please note that since the 2,5-FDCA based thermosets are cross-linked and insoluble, dissolution of the thermosets is only possible upon chemical breakdown. Therefore, the dissolution observed in these degradation studies is likely a result from ester bond hydrolysis and consecutive dissolution of the hydrolyzed products, as has also been reported for BP-C ${ }_{x}$ based polyesters by Miller and co-workers. ${ }^{11}$ This therefore indicates that hydrolysis is rather slow in demineralized water but is enhanced in alkaline conditions. Interestingly, the hydrolysis of the thermoset is significantly enhanced upon the addition of enzyme to polymer in buffer as full dissolution of the thermoset is observed within $48 \mathrm{~h}$ of incubation. Addition of enzyme to polymer in only water does not enhance the hydrolysis rate to such an extent as the polymer merely swells over time. This strongly suggests that the combination of enzyme and buffer facilitates depolymerization of the thermoset through hydrolysis.

Indeed, this seems to be the case when looking at the UV response of the ensuing mixtures. As is visible from Figure 11C, UV absorption is observed for all the samples below 300-320 $\mathrm{nm}$, likely indicating the presence of hydrolysis product BHFDA. No primary amines are detected upon addition of TNBS for the polymers immersed in water, buffer, or enzyme solution in water, indicating that only hydrolysis of the ester bonds takes place under these conditions. Interestingly, addition of TNBS to the system containing both buffer and enzyme results in a rapid color change of the solution and a rise in $\mathrm{UV}$ absorption maximum at 420. These preliminary findings indicate that the enzyme is able to also break down the amide bonds, thereby producing primary amines.

Though this absorption of water and consecutive enzymatic depolymerization show potential for biodegradability of the material, it may be desired to increase the lifetime of the thermosets in the presence of water. One potential route to control the depolymerization rate is by controlling the crosslinking density of the thermosets: An increase in cross-linking density increases the $T_{\mathrm{g}}$ and decreases the tendency of the thermosets to absorb water. As a result, the depolymerization process is expected to slow down, and thermosets with controlled degradation rates can be developed.

Detailed studies related to the degradation mechanism and products of the developed thermosets as a function of chemical composition and cross-linking density are currently ongoing and will be part of future communications. 


\section{CONCLUSIONS}

The synthesis of fully renewable bis(pyrrolidone) based dicarboxylic acids was shown to be readily achieved in bulk with only water as catalyst. Furthermore, these materials have shown to be excellent candidates for curing in 2-oxazoline based resins: Both GPC and NMR data indicate that the $\mathrm{BP}_{-} \mathrm{C}_{x}$ monomers improve the reaction rate, thus allowing for faster curing. Additionally, through FTIR characterization we observed that the reaction kinetics in 2-oxazoline based resins can be controlled by a judicious selection of the reactants; the $k_{1}$ reaction constant, responsible for chain extension, can be tailored by the choice of the dicarboxylic acid component, whereas the $k_{2}$ reaction constant, responsible for branching and cross-linking, can be controlled by the choice of the bis (2oxazoline) reactant. Combined, these provide a toolbox for the development of fully renewable and highly reactive resins with tailored thermal properties. Furthermore, the developed thermosets in this study are readily plasticized by water and are promising candidates for biodegradation as they are susceptible for enzymatic depolymerization.

\section{ASSOCIATED CONTENT}

\section{S Supporting Information}

The Supporting Information is available free of charge on the ACS Publications website at DOI: 10.1021/acssuschemeng.7b04716.

Information regarding the synthesis and NMR characterization of $\mathrm{BP}^{-\mathrm{C}_{x}}$ monomers, relation between glass transition temperature of $\mathrm{BP}-\mathrm{C}_{x}$ monomers and the hydrogen bonding density, 2-oxazoline conversion determination procedure using NMR spectroscopy, FTIR analysis of IAox and/or TPP based systems, verification of enhanced $k_{1}$ reaction constant on the rate of crosslinking, and reaction kinetics of FDCAox based systems containing various dicarboxylic acids (PDF)

\section{AUTHOR INFORMATION}

\section{Corresponding Author}

*E-mail: karel.wilsens@maastrichtuniversity.nl.

ORCID

Sanjay Rastogi: 0000-0002-7804-7349

Carolus H. R. M. Wilsens: 0000-0003-3063-9510

\section{Notes}

The authors declare no competing financial interest.

\section{ACKNOWLEDGMENTS}

This work is part of the research program and funded by Aachen Maastricht Institute of Biobased materials (AMIBM).

\section{REFERENCES}

(1) Gandini, A.; Belgacem, M. Furans in Polymer Chemistry. Prog. Polym. Sci. 1997, 22, 1203-1379.

(2) Robert, T.; Friebel, S. Itaconic acid-a versatile building block for renewable polyesters with enhanced functionality. Green Chem. 2016, 18 (10), 2922-2934.

(3) Winkler, M.; Lacerda, T. M.; Mack, F.; Meier, M. A. Renewable polymers from itaconic acid by polycondensation and ring-openingmetathesis polymerization. Macromolecules 2015, 48 (5), 1398-1403.

(4) van Putten, R.-J.; van der Waal, J. C.; de Jong, E.; Rasrendra, C. B.; Heeres, H. J.; de Vries, J. G. Hydroxymethylfurfural, A Versatile Platform Chemical Made from Renewable Resources. Chem. Rev. 2013, 113, 1499-1597.
(5) Wang, J.; Liu, X.; Zhang, Y.; Liu, F.; Zhu, J. Modification of poly(ethylene 2,5-furandicarboxylate) with 1,4-cyclohexanedimethylene: Influence of composition on mechanical and barrier properties. Polymer 2016, 103, 1-8.

(6) Deng, J.; Liu, X.; Li, C.; Jiang, Y.; Zhu, J. Synthesis and properties of a bio-based epoxy resin from 2,5-furandicarboxylic acid (FDCA). RSC Adv. 2015, 5, 15930-15939.

(7) Dai, J.; Ma, S.; Wu, Y.; Han, L.; Zhang, L.; Zhu, J.; Liu, X. Polyesters derived from itaconic acid for the properties and bio-based content enhancement of soybean oil-based thermosets. Green Chem. 2015, 17 (4), 2383-2392.

(8) Dai, J.; Ma, S.; Teng, N.; Dai, X.; Shen, X.; Wang, S.; Liu, X.; Zhu, J. 2, 5-Furandicarboxylic Acid-and Itaconic Acid-Derived Fully Biobased Unsaturated Polyesters and Their Cross-Linked Networks. Ind. Eng. Chem. Res. 2017, 56 (10), 2650-2657.

(9) Seppälä, J. V.; Helminen, A. O.; Korhonen, H. Degradable polyesters through chain linking for packaging and biomedical applications. Macromol. Biosci. 2004, 4 (3), 208-217.

(10) Cowie, J. M.; Haq, Z. Poly (mono n-alkyl itaconic acid esters): Their preparation and some physical properties. Br. Polym. J. 1977, 9 (3), 241-245.

(11) Qi, P.; Chen, H.-L.; Nguyen, H. T. H.; Lin, C.-C.; Miller, S. A. Synthesis of biorenewable and water-degradable polylactam esters from itaconic acid. Green Chem. 2016, 18 (15), 4170-4175.

(12) Dai, J.; Ma, S.; Liu, X.; Han, L.; Wu, Y.; Dai, X.; Zhu, J. Synthesis of bio-based unsaturated polyester resins and their application in waterborne UV-curable coatings. Prog. Org. Coat. 2015, 78, 49-54.

(13) Farmer, T. J.; Castle, R. L.; Clark, J. H.; Macquarrie, D. J. Synthesis of unsaturated polyester resins from various bio-derived platform molecules. Int. J. Mol. Sci. 2015, 16 (7), 14912-14932.

(14) Ali, M. A.; Tateyama, S.; Oka, Y.; Kaneko, D.; Okajima, M. K.; Kaneko, T. Syntheses of high-performance biopolyamides derived from itaconic acid and their environmental corrosion. Macromolecules 2013, 46 (10), 3719-3725.

(15) Ayadi, F.; Mamzed, S.; Portella, C.; Dole, P. Synthesis of bis (pyrrolidone-4-carboxylic acid)-based polyamides derived from renewable itaconic acid-application as a compatibilizer in biopolymer blends. Polym. J. 2013, 45 (7), 766-774.

(16) Chau, N.; Matsuda, S.; Iwakura, Y. Synthesis of polyamides from esteramide-diamines. Makromol. Chem. 1979, 180 (6), 1435-1440.

(17) Wang, Z.; Wei, T.; Xue, X.; He, M.; Xue, J.; Song, M.; Wu, S.; Kang, H.; Zhang, L.; Jia, Q. Synthesis of fully bio-based polyamides with tunable properties by employing itaconic acid. Polymer 2014, 55 (19), 4846-4856.

(18) Lv, A.; Li, Z.-L.; Du, F.-S.; Li, Z.-C. Synthesis, functionalization, and controlled degradation of high molecular weight polyester from itaconic acid via ADMET polymerization. Macromolecules 2014, 47 (22), 7707-7716.

(19) Goerz, O.; Ritter, H. Polymers with shape memory effect from renewable resources: crosslinking of polyesters based on isosorbide, itaconic acid and succinic acid. Polym. Int. 2013, 62 (5), 709-712.

(20) Gao, C.; Wang, J.; Han, S.; Hu, Z.; Liu, Y. Copolymerization modification of poly (butylene itaconate). In AIP Conference Proceedings; AIP Publishing, 2017; p 020221. DOI: 10.1063/1.4993038.

(21) He, M.; Wang, Z.; Wang, R.; Zhang, L.; Jia, Q. Preparation of BioBased Polyamide Elastomer by Using Green Plasticizers. Polymers 2016, 8 (7), 257.

(22) Chen, K.-S.; Ku, Y.-A.; Lin, H.-R.; Yan, T.-R.; Sheu, D.-C.; Chen, T.-M.; Lin, F.-H. Preparation and characterization of $\mathrm{pH}$ sensitive poly (N-vinyl-2-pyrrolidone/itaconic acid) copolymer hydrogels. Mater. Chem. Phys. 2005, 91 (2), 484-489.

(23) Coşkun, R. Graft copolymerization of itaconic acid-methacrylamide comonomers onto poly (ethylene terephthalate) fibers. Eur. Polym. J. 2007, 43 (4), 1428-1435.

(24) Sabaa, M.; Mokhtar, S. Chemically induced graft copolymerization of itaconic acid onto cellulose fibers. Polym. Test. 2002, 21 (3), 337-343. 
(25) Ouyang, Q.; Cheng, L.; Wang, H.; Li, K. Mechanism and kinetics of the stabilization reactions of itaconic acid-modified polyacrylonitrile. Polym. Degrad. Stab. 2008, 93 (8), 1415-1421.

(26) Hoogenboom, R. Poly (2-oxazoline) s: a polymer class with numerous potential applications. Angew. Chem., Int. Ed. 2009, 48 (43), 7978-7994.

(27) Hoogenboom, R.; Schlaad, H. Bioinspired poly (2-oxazoline)s. Polymers 2011, 3 (1), 467-488.

(28) Lava, K.; Verbraeken, B.; Hoogenboom, R. Poly (2-oxazoline) s and click chemistry: a versatile toolbox toward multi-functional polymers. Eur. Polym. J. 2015, 65, 98-111.

(29) Sedlacek, O.; Monnery, B. D.; Filippov, S. K.; Hoogenboom, R.; Hruby, M. Poly (2-Oxazoline) s-Are They More Advantageous for Biomedical Applications Than Other Polymers? Macromol. Rapid Commun. 2012, 33 (19), 1648-1662.

(30) Luxenhofer, R.; Han, Y.; Schulz, A.; Tong, J.; He, Z.; Kabanov, A. V.; Jordan, R. Poly (2-oxazoline) s as Polymer Therapeutics. Macromol. Rapid Commun. 2012, 33 (19), 1613-1631.

(31) Luxenhofer, R.; Sahay, G.; Schulz, A.; Alakhova, D.; Bronich, T. K.; Jordan, R.; Kabanov, A. V. Structure-property relationship in cytotoxicity and cell uptake of poly (2-oxazoline) amphiphiles. J. Controlled Release 2011, 153 (1), 73-82.

(32) Luxenhofer, R.; Schulz, A.; Roques, C.; Li, S.; Bronich, T. K.; Batrakova, E. V.; Jordan, R.; Kabanov, A. V. Doubly amphiphilic poly (2oxazoline) $\mathrm{s}$ as high-capacity delivery systems for hydrophobic drugs. Biomaterials 2010, 31 (18), 4972-4979.

(33) Persigehl, P.; Jordan, R.; Nuyken, O. Functionalization of amphiphilic poly (2-oxazoline) block copolymers: A novel class of macroligands for micellar catalysis. Macromolecules 2000, 33 (19), 6977-6981.

(34) Jordan, R.; West, N.; Ulman, A.; Chou, Y.-M.; Nuyken, O. Nanocomposites by surface-initiated living cationic polymerization of 2oxazolines on functionalized gold nanoparticles. Macromolecules 2001, 34 (6), 1606-1611.

(35) Culbertson, B. M. Cyclic imino ethers in step-growth polymerizations. Prog. Polym. Sci. 2002, 27 (3), 579-626.

(36) Kagiya, T.; Narisawa, S.; Maeda, T.; Fukui, K. Ring-opening polymerization of 2-substituted 2-oxazolines. J. Polym. Sci., Part B: Polym. Lett. 1966, 4 (7), 441-445.

(37) Kagiya, T.; Narisawa, S.; Maeda, T.; Fukui, K. Preparation of a crystalline poly (ester-amide) by the polyaddition reaction of bisoxazoline and a dicarboxylic acid. J. Polym. Sci., Part B: Polym. Lett. 1966, 4 (4), 257-260.

(38) Lustoň, J.; Kronek, J.; Böhme, F. Synthesis and polymerization reactions of cyclic imino ethers. I. Ring-opening homopolyaddition of AB-type hydroxyphenyl-substituted 2-oxazolines. J. Polym. Sci., Part A: Polym. Chem. 2006, 44 (1), 343-355.

(39) Lustoň, J.; Kronek, J.; Markus, O.; Janigová, I.; Böhme, F. Synthesis and polymerization reactions of cyclic imino ethers. 3. Poly (ester amide) $s$ of the AA+ BB type on the basis of 2-oxazolines. Polym. Adv. Technol. 2007, 18 (2), 165-172.

(40) Kangani, C. O.; Kelley, D. E. One pot direct synthesis of amides or oxazolines from carboxylic acids using Deoxo-Fluor reagent. Tetrahedron Lett. 2005, 46 (51), 8917-8920.

(41) Kangani, C. O.; Kelley, D. E.; Day, B. W. One pot direct synthesis of oxazolines, benzoxazoles, and oxadiazoles from carboxylic acids using the Deoxo-Fluor reagent. Tetrahedron Lett. 2006, 47 (37), 6497-6499.

(42) Kempe, K.; Lobert, M.; Hoogenboom, R.; Schubert, U. S. Screening the synthesis of 2-substituted-2-oxazolines. J. Comb. Chem. 2009, 11 (2), 274-280.

(43) Pirrung, M. C.; Tumey, L. N. Oxazoline Synthesis from Hydroxyamides by Resin Capture and Ring-Forming Release. J. Comb. Chem. 2000, 2 (6), 675-680.

(44) Wipf, P.; Venkatraman, S. From aziridines to oxazolines and thiazolines: The heterocyclic route to thiangazole. Synlett 1997, 1 (01), $1-10$.

(45) Cwik, A.; Hell, Z.; Hegedüs, A.; Finta, Z.; Horváth, Z. A simple synthesis of 2-substituted oxazolines and oxazines. Tetrahedron Lett. 2002, 43 (22), 3985-3987.
(46) Bodner, T.; Ellmaier, L.; Schenk, V.; Albering, J.; Wiesbrock, F. Delocalized $\pi$-electrons in 2-oxazoline rings resulting in negatively charged nitrogen atoms: revealing the selectivity during the initiation of cationic ring-opening polymerizations. Polym. Int. 2011, 60 (8), 11731179.

(47) Böhme, F.; Clausnitzer, C.; Gruber, F.; Grutke, S.; Huber, T.; Pötschke, P.; Voit, B. Hyperbranched poly (ether amide) s via nucleophilic ring opening reaction of oxazolines. High Perform. Polym. 2001, 13 (2), S21-S31.

(48) Huber, T.; Böhme, F.; Komber, H.; Kronek, J.; Luston, J.; Voigt, D.; Voit, B. New hyperbranched poly (ether amide) s via nucleophilic ring opening of 2-oxazoline-containing monomers. Macromol. Chem. Phys. 1999, 200 (1), 126-133.

(49) Jakisch, L.; Böhme, F.; Komber, H.; Pompe, G. Synthesis and thermal polymerization of aromatic 2-oxazolines containing carboxylic groups. Macromol. Rapid Commun. 1999, 20 (5), 256-260.

(50) Sano, Y. Polymerization of bis (2-oxazoline) compounds with dicarboxylic acids. J. Polym. Sci., Part A: Polym. Chem. 1989, 27 (8), 2749-2760.

(51) Sano, Y.; Arita, K.; Masuda, I. Cross-linked polyesteramide from bis (2-oxazoline). Patent US4474942A, 1984.

(52) Nery, L.; Lefebvre, H.; Fradet, A. Kinetic and Mechanistic Studies of Carboxylic Acid-Bisoxazoline Chain-Coupling Reactions. Macromol. Chem. Phys. 2003, 204 (14), 1755-1764.

(53) Tuominen, J.; Seppälä, J. V. Synthesis and Characterization of Lactic Acid Based Poly (ester- amide). Macromolecules 2000, 33 (10), 3530-3535.

(54) Tarvainen, T.; Karjalainen, T.; Malin, M.; Pohjolainen, S.; Tuominen, J.; Seppälä, J.; Järvinen, K. Degradation of and drug release from a novel 2, 2-bis (2-oxazoline) linked poly (lactic acid) polymer. $J$. Controlled Release 2002, 81 (3), 251-261.

(55) Kylmä, J.; Tuominen, J.; Helminen, A.; Seppälä, J. Chain extending of lactic acid oligomers. Effect of 2, 2'-bis (2-oxazoline) on 1, 6-hexamethylene diisocyanate linking reaction. Polymer 2001, 42 (8), $3333-3343$

(56) Lustoň, J.; Kronek, J.; Böhme, F.; Komber, H. Azo-group labelled polyesters by end-capping with 2-oxazoline derivatives-preparation. In Macromolecular Symposia; Wiley Online Library, 2001; pp 105-116. DOI: 10.1002/1521-3900(200102) 164:1<105::AID-MASY105>3.0. $\mathrm{CO} ; 2-\mathrm{H}$.

(57) Wilsens, C. H.; Wullems, N. J.; Gubbels, E.; Yao, Y.; Rastogi, S.; Noordover, B. A. Synthesis, kinetics, and characterization of bio-based thermosets obtained through polymerization of a 2, 5-furandicarboxylic acid-based bis (2-oxazoline) with sebacic acid. Polym. Chem. 2015, 6 (14), 2707-2716

(58) Gashti, M. P.; Assefipour, R.; Kiumarsi, A.; Gashti, M. P. Enzymatic surface hydrolysis of polyamide 6, 6 with mixtures of proteolytic and lipolytic enzymes. Prep. Biochem. Biotechnol. 2013, 43 (8), 798-814.

(59) Silva, C.; Araújo, R.; Casal, M.; Gübitz, G. M.; Cavaco-Paulo, A. Influence of mechanical agitation on cutinases and protease activity towards polyamide substrates. Enzyme Microb. Technol. 2007, 40 (7), $1678-1685$.

(60) Song, A. R.; Kim, H. R. Effectiveness of flavourzyme treatment on polyamide fabric. Fibers Polym. 2013, 14 (12), 2212-2220.

(61) Fazio, M. J. Nucleophilic ring opening of 2-oxazolines with amines: a convenient synthesis for unsymmetrically substituted ethylenediamines. J. Org. Chem. 1984, 49 (25), 4889-4893.

(62) Cui, X.; Yan, D. Preparation, characterization and crystalline transitions of odd-even polyamides 11, 12 and 11, 10. Eur. Polym. J. 2005, 41 (4), 863-870.

(63) Blumstein, A.; Thomas, O. Odd-even effect in thermotropic liquid crystalline 4, 4' -dihydroxy-2, 2' -dimethylazoxybenzene-alkanedioic acid polymer. Macromolecules 1982, 15 (5), 1264-1267.

(64) Satake, K.; Okuyama, T.; Ohashi, M.; Shinoda, T. The Spectrophotometric Determination of Amine, Amino acid, and Peptide with 2,4,6-trinitrobenzene-1-sulfonic acid. J. Biochem. 1960, 47 (5), 654-660. 
(65) Cayot, P.; Tainturier, G. The Quantification of Protein Amino Groups by the Trinitrobenzenesulfonic Acid Method: A Reexamination. Anal. Biochem. 1997, 249, 184-200.

(66) Silva, C.; Cavaco-Paulo, A. Monitoring Biotransformations in Polyamide Fibres. Biocatal. Biotransform. 2004, 22, 357-360.

(67) Spadaro, A. C. C.; Draghetta, W.; Del Lama, S. N.; Camargo, A. C. M.; Greene, L. J. A Convenient Manual Trinitrobenzenesulfonic Acid Method for Monitoring Amino Acids and Peptides in Chromatographic Column Effluents. Anal. Biochem. 1979, 96, 317-321.

(68) Bubnis, W. A.; Ofner, C. M., III The Determination of $\varepsilon$-Amino Groups in Soluble and Poorly Soluble Proteinaceous Materials by a Spectrophotometric Method Using Trinitrobenzenesulfonic Acid. Anal. Biochem. 1992, 207, 129-133.

(69) Kiranas, E. R.; Tzouwara-Karayanni, S. M.; Karayannis, M. I. The reaction of glutamic acid and trinitrobenzenesulfonic acid kinetic study and analytical application. Talanta 1997, 44, 1113-1121. 